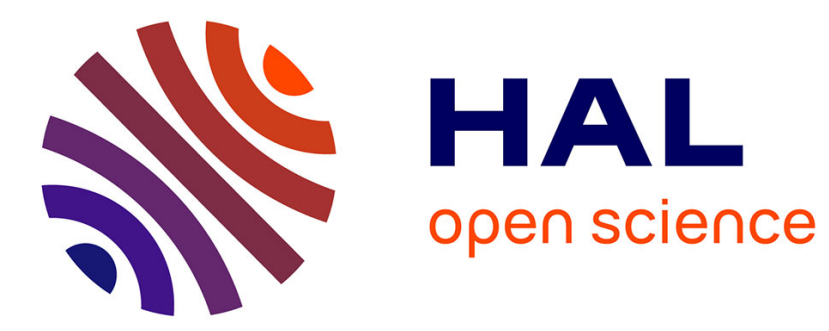

\title{
Influence of Chromium Carbides on the High Temperature Oxidation Behavior and on Chromium Diffusion in Nickel-Base Alloys \\ Patrice Berthod
}

\section{- To cite this version:}

Patrice Berthod. Influence of Chromium Carbides on the High Temperature Oxidation Behavior and on Chromium Diffusion in Nickel-Base Alloys. Oxidation of Metals, 2007, 68 (1-2), pp.77-96. 10.1007/s11085-007-9062-1 . hal-02181305

\section{HAL Id: hal-02181305 \\ https://hal.science/hal-02181305}

Submitted on 12 Jul 2019

HAL is a multi-disciplinary open access archive for the deposit and dissemination of scientific research documents, whether they are published or not. The documents may come from teaching and research institutions in France or abroad, or from public or private research centers.
L'archive ouverte pluridisciplinaire HAL, est destinée au dépôt et à la diffusion de documents scientifiques de niveau recherche, publiés ou non, émanant des établissements d'enseignement et de recherche français ou étrangers, des laboratoires publics ou privés. 


\section{Influence of chromium carbides on the high temperature oxidation behavior and on the chromium diffusion in nickel base alloys}

\section{Patrice Berthod}

Laboratoire de Chimie du Solide Minéral (UMR 7555), Université Henri Poincaré

BP 239, 54506 Vandoeuvre-lès-Nancy - France

E-mail: patrice.berthod@centraliens-lille.org

Two simple cast nickel alloys $\mathrm{Ni}$-30Cr-0.2C and $\mathrm{Ni}$-30Cr-0.8C were oxidized at 1000,1100 and $1200^{\circ} \mathrm{C}$. Their behaviors were characterized using thermogravimetry techniques and their parabolic and chromia volatilization constants were determined by analysing the $\mathrm{m} \cdot \frac{\mathrm{dm}}{\mathrm{dt}}$ versus $-\mathrm{m}$ curves. The obtained constants were generally in good agreement with experimental mass gain kinetics and chromium balance sheets. A higher carbon content i.e. a higher carbides density leads to higher values of the transient linear oxidation constant $K_{l}$, of the parabolic constant $K_{p}$, and obviously also of the volatilization constant $K_{v}$. Chromium diffusion coefficients through the zone affected by oxidation were calculated from oxidation kinetics and chromium gradients. They increase when carbide density increases.

KEY WORDS: Nickel alloys; Chromium carbides; High temperature oxidation; Chromia volatilization; Chromium diffusion

Post-print version of the article Oxid Met (2007) 68:77-96; DOI 10.1007/s1 1085-007-9062-1

\section{INTRODUCTION}

The high temperature oxidation of alloys containing a sufficient amount of chromium is limited by the rapid establishment of a continuous $\mathrm{Cr}_{2} \mathrm{O}_{3}$ layer on the external surface (Ref. 1). Thus chromium, which protects alloys from a too fast oxidation, is often used in industrial superalloys to resist high temperature oxidation by air or by other hot gases (Ref. 2 to 3). This element is also used to protect superalloys against corrosion by molten salts or glasses, by forming an external passivation chromia scale (Ref. 4 to 5 ).

In chromia-forming superalloys chromium is always present in solid solution in the matrix. Since it is also a carbide-former element, $\mathrm{Cr}$ can be present in carbides, e.g. in the alloys for which the mechanical strength is provided by interdendritic carbides. For such alloys the distribution of chromium between the matrix and the interdendritic carbides can influence the oxidation behavior by influencing the chromium diffusion towards the oxidation front. Such an effect was earlier seen on complex Ni-base and Co-base chromia-forming alloys (Ref. 6) for which there was a clear dependence of the high temperature oxidation rate on the carbon content i.e. on the density of the carbides network. But this influence remained difficult to explain because of the complex chemical compositions and of the presence of different types of carbides.

Here the influence of the chromium carbides on the high temperature oxidation behavior was studied at 1000 , 1100 and $1200^{\circ} \mathrm{C}$, for two alloys that can be considered as very simplified versions of real nickel base superalloys reinforced by carbides: an alloy with a low fraction of carbides (Ni-30Cr-0.2C) and another alloy with a higher fraction of carbides (Ni-30Cr-0.8C) (contents given in weight percent). The characterization of the oxidation behavior is achieved by the determination of both the parabolic constant $\mathrm{K}_{\mathrm{p}}$ and the chromia volatilization constant $\mathrm{K}_{\mathrm{v}}$. Indeed knowing the rate of mass loss due to the volatilization of chromia is important too since it allows a more precise determination of $\mathrm{K}_{\mathrm{p}}$ when the temperature is higher than $1000^{\circ} \mathrm{C}$. In addition, the volatilization behavior of chromia may also depend on the chromium carbides density or on the distribution of chromium between matrix and intergranular carbides, and it could be interesting to reveal and to study this possible dependence.

In order to determine $K_{v}$ several techniques are possible. First it is possible to look for a value of $K_{v}$ that allows a good description of the experimental mass gain curve by a $\left\{\mathrm{m}=\sqrt{2 \cdot \mathrm{K}_{\mathrm{p}}} \cdot \sqrt{\mathrm{t}}-\mathrm{K}_{\mathrm{v}} \cdot \mathrm{t}\right\}$-type 
equation where $\mathrm{m}$ is the mass gain per surface unit area (Ref. 7). It is also possible to use another technique based on the differential equation derived from the Wagner's theory (Ref. 8) in which the term $\left(\mathrm{K}_{\mathrm{V}} \cdot \mathrm{dt}\right)$ is subtracted from the mass gain $\mathrm{dm}$ (i.e. $\mathrm{dm}=\left(\mathrm{K}_{\mathrm{p}} / \mathrm{m}\right) \cdot \mathrm{dt}-\mathrm{K}_{\mathrm{v}} \cdot \mathrm{dt}$ ) and $\mathrm{m}$ is replaced by a function $m+k^{\prime}$. $t$. B where $B$ is a constant and $k^{\prime}$ is related to the volatilization rate (Ref. 9 to 10).

Here these two constants were determined by analysing the thermogravimetry data using a third method which was earlier presented in detail (Ref. 11), which is based on the equation $\mathrm{m} \cdot \frac{\mathrm{dm}}{\mathrm{dt}}=\mathrm{K}_{\mathrm{p}}-\mathrm{K}_{\mathrm{v}} \cdot \mathrm{m}$ and which will be shortly described later in the text. The diffusion rates of chromium for the two alloys were deduced from thermogravimetry results (taking chromia volatilization into account) and chromium contents profiles across the zone affected by oxidation. The obtained diffusion coefficients were studied with respect to the carbides density.

\section{EXPERIMENTAL METHOD}

\section{Synthesis of the Alloys and Oxidation Runs}

The two alloys $\mathrm{Ni}-30 \mathrm{Cr}-0.2 \mathrm{C}$ and $\mathrm{Ni}-30 \mathrm{Cr}-0.8 \mathrm{C}$ (weight percent) were elaborated by casting of ingots (mass $\approx 100 \mathrm{~g}$ ) in a cold crucible with a high frequency induction furnace, under an inert atmosphere (about 400mbar of pure Argon, $\left.\mathrm{H}_{2} \mathrm{O}<3 \mathrm{ppm}, \mathrm{O}_{2}<2 \mathrm{ppm}, \mathrm{C}_{\mathrm{n}} \mathrm{H}_{\mathrm{m}}<0.5 \mathrm{ppm}\right)$, and from pure Ni and $\mathrm{Cr}(>99.9$ wt.\%, Alfa Aesar) and graphite. Parallelepipeds (dimensions of about $10 \mathrm{~mm}$ x $10 \mathrm{~mm}$ x $3 \mathrm{~mm}$ ) were cut to obtain the samples for the thermogravimetry tests. Their surfaces were polished with SiC paper from 240 to 1200 grid under water. Oxidation tests were performed at 1000,1100 and $1200^{\circ} \mathrm{C}$ using a Setaram TGA92 thermobalance under a dry synthetic air flow $\left(80 \% \mathrm{~N}_{2}-20 \% \mathrm{O}_{2}\right)$ at $1.5 \mathrm{~L} / \mathrm{h}$. The test duration $(50$ hours) was long enough to get a sufficiently long parabolic oxidation stage after the initial transient oxidation. Temperature and mass gain values were recorded every 40 seconds.

\section{Mathematical Processing}

Before they reached the targeted test temperature, the samples encountered a first oxidation during heating, which was followed at the beginning of the isothermal stage by a second part of transient oxidation. The latter gave a linear mass gain (of the $\left\{\mathrm{m}=\mathrm{K}_{1}\right.$. dt $\}$-type with $\mathrm{K}_{1}$ expressed in $\mathrm{g} \mathrm{cm}^{-2} \mathrm{~s}^{-1}$ ) before the parabolic oxidation started. Thus, for all tests, the treatment of the mass gain results began with the determination of the linear constant $\mathrm{K}_{1}$. These $\mathrm{K}_{1}$ values for an alloy at the three test temperatures, which obviously obeyed an Arrhenius law, allow estimating the mass gain obtained during the heating. This first mass gain can be thereafter added to the isothermal mass gain obtained during the second part of the transient oxidation. Then the initial mass gain $\mathrm{m}_{0}$ can be known before considering the parabolic or pseudo-parabolic part. This procedure was entirely described in a previous work (Ref. 11).

The analysis of the thermogravimetry results for quantifying both the parabolic rate and the volatilization rate were performed considering the equation (1), which can also be written with a second form (equation 2) in which the first member appears to be a linear function of $\mathrm{m}$ :

$$
\mathrm{dm}=\frac{\mathrm{K}_{\mathrm{p}}}{\mathrm{m}} \cdot \mathrm{dt}-\mathrm{K}_{\mathrm{v}} \cdot \mathrm{dt} \quad \mathrm{m} \cdot \frac{\mathrm{dm}}{\mathrm{dt}}=\mathrm{K}_{\mathrm{p}}-\mathrm{K}_{\mathrm{v}} \cdot \mathrm{m}
$$

where $\mathrm{m}$ and $\mathrm{dm}$ are expressed in $\mathrm{g} \mathrm{cm}^{-2}, \mathrm{~K}_{\mathrm{p}}$ in $\mathrm{g}^{2} \mathrm{~cm}^{-4} \mathrm{~s}^{-1}$ and $\mathrm{K}_{\mathrm{v}}$ in $\mathrm{g} \mathrm{cm}^{-2} \mathrm{~s}^{-1}$.

Plotting $\mathrm{m} \cdot \frac{\mathrm{dm}}{\mathrm{dt}}$ versus $-\mathrm{m}$ may lead to a straight line, the ordinate at the origin and the slope of which are respectively $\mathrm{K}_{\mathrm{p}}$ and $\mathrm{K}_{\mathrm{v}}$. This can be verified by drawing a mathematical curve which is typical of a mass gain kinetic of a chromia-forming alloy oxidised at $\mathrm{T}>>1000^{\circ} \mathrm{C}$ (mass loss due to the volatilization of chromia, Fig. 1 a) or typical of a pure parabolic mass gain kinetic $\left(\mathrm{T}<1000^{\circ} \mathrm{C}\right.$, absence of chromia volatilization, Fig. 1 b). Such theoretic mass gain curves can be obtained by computing the curves according 
to equation (3) from values arbitrarily given to $\mathrm{K}_{\mathrm{p}}$ and $\mathrm{K}_{\mathrm{v}}$ (here the values are chosen to be characteristic of the constants that are usually measured for alloys of the same family) where the next total mass gain $\mathrm{m}_{\mathrm{n}+1}$ at the step $\mathrm{n}+1$ (i.e. at $\mathrm{t}=(\mathrm{n}+1) . \Delta \mathrm{t}$ where $\Delta \mathrm{t}$ is the time step) is the sum of the total mass gain $\mathrm{m}_{\mathrm{n}}$ at the previous step $n$ and of the elementary mass gain $\mathrm{dm}_{\mathrm{n}+1}$ calculated according to equation (4):

$$
\mathrm{m}_{\mathrm{n}+1}=\mathrm{m}_{\mathrm{n}}+\mathrm{dm}_{\mathrm{n}+1}
$$

$$
\mathrm{dm}_{\mathrm{n}+1}=\frac{\mathrm{K}_{\mathrm{p}}}{\mathrm{m}_{\mathrm{n}}} \cdot \mathrm{dt}-\mathrm{K}_{\mathrm{v}} \cdot \mathrm{dt}
$$

The obtained mathematical curves show that a significant value of $\mathrm{K}_{\mathrm{v}}$ (that simulates a noticeable volatilization of chromia) leads to a tilted straight line (first curve, Fig. 1 a) while a $K_{v}$ equal to zero (no chromia volatilization) leads on the contrary to a horizontal straight line (second curve, Fig. 1 b). The treatment according to equation (2) effectively gives values (see the equations of the regression straight lines in the graphs) that are equal to the values of $\mathrm{Kp}$ and $\mathrm{Kv}$ that were initially injected. The initial part of the curve (on the right side) shows $\mathrm{m} \cdot \frac{\mathrm{dm}}{\mathrm{dt}}$ values that are particularly high since the hypothesis made in Ref. 11 to obtain equation (2) is not really respected at the beginning of the parabolic oxidation (i.e. the ratio $\frac{\mathrm{m}}{\mathrm{m}_{\mathrm{O}}}, \mathrm{m}_{\mathrm{O}}$ being the oxygen mass, is not yet constant).

For real curves the small lack of precision of thermobalances leads to curves that are not so pure since the $\mathrm{m} \cdot \frac{\mathrm{dm}}{\mathrm{dt}}$ values tend to be a little unstable because of the derived term $\frac{\mathrm{dm}}{\mathrm{dt}}$. Then the values of $\frac{\mathrm{dm}}{\mathrm{dt}}$ were estimated by the regression coefficient calculated on the interval of the eleven successive couples $(t, m)$ centred on the considered time t. Thus, in the $\left\{\mathrm{m} \cdot \frac{\mathrm{dm}}{\mathrm{dt}}\right.$ versus $\left.-\mathrm{m}\right\}$-type graph each point corresponds to a step equal to 400 s and not to the initial recording step which was 40 s during the thermogravimetry tests. Thereafter, the variation of $\mathrm{m} \cdot \frac{\mathrm{dm}}{\mathrm{dt}}$ versus $-\mathrm{m}$ was plotted, the linearity of the last part of the obtained curve verified, and then the values of $\mathrm{K}_{\mathrm{p}}$ and $\mathrm{K}_{\mathrm{v}}$ deduced.

More accurate values of $\mathrm{K}_{\mathrm{v}}$ were determined first by taking into account the mass loss corresponding to the volatilization of the platinum suspension. The latter was measured by performing tests without samples, that lead to volatilization rates of $\mathrm{R}_{\text {susp }}=0.93 \times 10^{-10} \mathrm{~g} \mathrm{~s}^{-1}\left(1000^{\circ} \mathrm{C}\right), 4.5 \times 10^{-10} \mathrm{~g} \mathrm{~s}^{-1}\left(1100^{\circ} \mathrm{C}\right)$ and $26.3 \times 10^{-}$ ${ }^{10} \mathrm{~g} \mathrm{~s}^{-1}\left(1200^{\circ} \mathrm{C}\right)$, that allowed to add a $\mathrm{R}_{\text {susp }} \mathrm{t}$ linear term to the mass gain recorded by the thermobalance, before division by the sample surface. Second, it was seen on samples after oxidation tests that a carbide-free zone grew from the external surface of the sample, with a depth supposed to obey a $\{\mathrm{d}(\mathrm{t})=$ constant $x \sqrt{\mathrm{t}}\}$-type diffusion-controlled law (like it was previously observed by microscopy examination for other carbidesreinforced alloys after oxidation during several durations). In order to do not minimize the real mass gain due to the sole oxidation of chromium, the loss of carbon that initially belonged to the disappearing carbides in the alloy was taken into account. This was done by adding to the measured mass gain a term $\mathrm{R}_{\mathrm{C}}(\mathrm{t})$ calculated according to equation (5), before division by the sample surface and treatment with respect to equation (2):

$$
\mathrm{R}_{\mathrm{C}}(\mathrm{t})=\rho_{\text {alloy }} \cdot \mathrm{S} \cdot \mathrm{W}_{\mathrm{C} \text { alloy }} \cdot \mathrm{d}_{\mathrm{cfz}} \cdot \sqrt{\frac{\mathrm{t}}{\Delta \mathrm{t}_{\text {stage }}}} .
$$

where $\rho_{\text {alloy }}$ is the density of the alloy (about $8.2 \mathrm{~g} \mathrm{~cm}^{-3}$ for the two alloys), $S$ the external surface of the sample, $d_{\text {cfz }}$ is the depth of the carbide-free zone measured by microscopy on the sample after the thermogravimetry test, $\mathrm{W}_{\mathrm{C} \text { alloy }}$ is the carbon weight content of the alloy, $\mathrm{t}$ the time counted since the beginning of the isothermal stage and $\Delta \mathrm{t}_{\text {stage }}$ the total duration of this stage.

\section{Metallographic Study}

The oxidized samples were covered using cathodic evaporation of gold in order to give a good electrical conductivity to the external oxide scale. Thereafter a layer of electrolytic nickel was deposited on the 
external oxide to protect it from mechanical stresses. Each sample was cut in two parts using an Accutom-2 saw equipped with a diamond blade. It was embedded in an epoxy resin, then polished with SiC paper from 120 to 1200 grid under water. The final polishing was realized using a $1 \mu \mathrm{m}$-diamond suspension.

An optical microscope equipped with a graduated ocular was used to observe the oxidation front of the samples and to measure the thickness of the oxide scale on the areas where it partly remained after test. The oxide thickness was assessed by the calculation of the average value of about twenty measures, and of the interval of uncertainty defined by the standard deviation.

The samples were also examined using a Scanning Electron Microscope (SEM) Philips XL30 in Back Scattered Electrons (BSE) mode with an acceleration voltage of 20kV. Its Energy Dispersive Spectroscopy (EDS) device was used to verify the real chemical composition of the obtained alloy (except carbon) and to identify the external oxide layer, as well as the internal oxides when present.

Two chromium profiles measurements were performed for each sample by Wavelength Dispersion Spectrometry (WDS) using a Cameca SX100 microprobe, in order to value the total oxidized chromium and the chromium gradients in the zone affected by oxidation.

\section{RESULTS}

\section{Characteristics of the Obtained Alloys}

The alloys microstructures are composed of a dendritic nickel fcc matrix and of $\mathrm{Cr}_{7} \mathrm{C}_{3}$ carbides that are present in the grain boundaries. These chromium carbides are dispersed and in small quantity in the $\mathrm{Ni}-30 \mathrm{Cr}-$ $0.2 \mathrm{C}$ alloy. They are more present and form a continuous interdendritic network in the Ni-30Cr-0.8C alloy, in which the austenitic dendrites are more visible and characterized by an average space between two successive secondary arms of about $30 \mu \mathrm{m}$. The obtained chemical compositions, which were measured on $0.2 \mathrm{~mm}^{2}$ areas using the EDS apparatus of the MEB, are given in Table I. The obtained Ni and Cr contents are very close to the targeted ones. The too low carbon contents cannot be measured by SEM/EDS or microprobe but the obtained microstructures showed that the two targeted values, 0.2 and 0.8 , were obviously reached too. Indeed, the surface fractions of the chromium carbides observed in the present alloys are very close to the surface fractions obtained earlier on other similar alloys with the same carbon contents (which were measured using spark-source mass spectrometry). It is not surprising since carbon contents are usually well respected for the elaboration procedure that was used here too.

\section{Thermogravimetry Results}

The graph presented in Fig. 2 shows the isothermal mass gain curves obtained for the two alloys for the three temperatures. It appears that all curves become parabolic after a first more or less extended linear oxidation part, which is generally longer for the Ni-30Cr-0.8C alloy than for the Ni-30Cr-0.2C alloy. It is a first reason why the mass gain curves of the high carbon alloy are all above than the curves corresponding to the other alloy for the same temperatures. But, in addition, the parabolic oxidation is also often faster for Ni$30 \mathrm{Cr}-0.8 \mathrm{C}$ than for $\mathrm{Ni}-30 \mathrm{Cr}-0.2 \mathrm{C}$.

The $\mathrm{m} . \frac{\mathrm{dm}}{\mathrm{dt}}$ versus $-\mathrm{m}$ curves were plotted in Fig. 3 and Fig. 4 for respectively the Ni-30Cr-0.2C and Ni-30Cr-0.8C alloys for 1100 and $1200^{\circ} \mathrm{C}$, temperatures that allow a significant rate of chromia volatilization. As seen earlier on synthetic curves (Fig. 1), all curves begin here (on the right of the graphs) by particularly high points, for the reason given previously. In some cases this also may be due to the very sensitive $\frac{\mathrm{dm}}{\mathrm{dt}}$ factor value, as long as the external chromia scale is not perfectly continuous. The second part of the curve (on the left of the graphs) is almost linear, although the $\mathrm{m} \cdot \frac{\mathrm{dm}}{\mathrm{dt}}$ values (more precisely the $\frac{\mathrm{dm}}{\mathrm{dt}}$ values) are more or less scattered. Fortunately, this dispersion becomes smaller when the test temperature increases, as is to say when the mass gain during $\mathrm{dt}$ is greater for all times and then less affected by the lack of precision of the thermobalance. 
The determination of the $\mathrm{K}_{1}$ constants leads to the values given in Table II by which an Arrhenius plot was derived (Fig. 5 a), for determination of the activation energies. For comparison the corresponding values that were previously obtained for a simple Ni-30wt.\% Cr binary alloy (Ref. 11) are added. It appears that the $\mathrm{K}_{1}$ constant increases with temperature and obviously obeys an Arrhenius law, but it also depends on the carbon content. If for $1000^{\circ} \mathrm{C} \mathrm{K}$ is lower for the $\mathrm{Ni}-30 \mathrm{Cr}-0.2 \mathrm{C}$ alloy than for the other alloy, this difference becomes smaller for $1100^{\circ} \mathrm{C}$ and this order is inverted for $1200^{\circ} \mathrm{C}$. Indeed the activation energy should be decreased by the presence of a high quantity of carbides. This becomes more obvious when the results obtained earlier for the $\mathrm{Ni}-30 \% \mathrm{Cr}$ alloy (without carbides then close to the $\mathrm{Ni}-30 \mathrm{Cr}-0.2 \mathrm{C}$ alloy) are taken into account. However, on the $1000-1200^{\circ} \mathrm{C}$ range it can be considered that $\mathrm{K}_{1}$ generally increases with the carbon content.

The values of the parabolic constant $\mathrm{K}_{\mathrm{p}}$ are displayed in Table III, with also three points plotted in a $\ln \left(\mathrm{K}_{\mathrm{p}}\right)$ versus 1/T graph for the two alloys in Fig. 5 b. When carbides are present, the increasing of the parabolic constant with the carbides amount, which was already observed for other alloys (Ref. 6), is found again here between the two studied alloys. This remains true when the results previously obtained for the Ni-30\% $\mathrm{Cr}$ alloy are added. Indeed, the parabolic constant is the lowest when there are no carbides in grain boundaries. The parabolic constant almost follows an Arrhenius law (Fig. 5 b) but the calculated activation energies are sensibly lower for the carbides-containing alloys than for the $\mathrm{Ni}-30 \% \mathrm{Cr}$ alloy.

Table III also displays the values of the constant $\mathrm{K}_{\mathrm{v}}$. The volatilization of chromia already exists for $1000^{\circ} \mathrm{C}$ but logically with the lowest values of $\mathrm{K}_{\mathrm{v}}$. The volatilization constant appears to be of the same order of magnitude between the two carbides-containing alloys and the binary alloy (except for $1000^{\circ} \mathrm{C}$ for which $\mathrm{K}_{\mathrm{v}}$ is negligible for the binary alloy). Although these values cannot be clearly ordered with regards to the carbon content of the alloy, it seems that carbon or carbides tend to increase chromia volatilization. Like for the $\mathrm{K}_{\mathrm{p}}$ constant, the $K_{v}$ constant seems to obey an Arrhenius law (Fig. 5 c) and the activation energy seems to increase with the carbide density. This can explain why there is not a clear dependence of $\mathrm{K}_{\mathrm{v}}$ on the carbon content for all temperatures.

Knowing the values of the initial mass gain before parabolic oxidation, of $K_{p}$ and of $K_{v}$, it is now possible to plot the mathematical mass gain curves, for comparison with the corresponding experimental thermogravimetry curves. This was done in Fig. 6 for 1100 and $1200^{\circ} \mathrm{C}$ in which the successive points were determined using the equation (6) where $m_{n+1}$ is the mass gain at $t=t_{o}+(n+1)$.dt and $m_{0}$ is the mass gain at the end of the isothermal transient oxidation:

$$
\mathrm{m}_{\mathrm{n}+1}=\mathrm{m}_{\mathrm{n}}+\frac{\mathrm{K}_{\mathrm{p}}}{\mathrm{m}_{\mathrm{n}}} \cdot \mathrm{dt}-\mathrm{K}_{\mathrm{v}} \cdot \mathrm{dt}
$$

with $\mathrm{m}_{\mathrm{n}}$ and $\mathrm{m}_{\mathrm{n}+1}$ expressed in $\mathrm{g} \mathrm{cm}^{-2}, \mathrm{~K}_{\mathrm{p}}$ in $\mathrm{g}^{2} \mathrm{~cm}^{-4} \mathrm{~s}^{-1}$, and $\mathrm{K}_{\mathrm{v}}$ in $\mathrm{g} \mathrm{cm}^{-2} \mathrm{~s}^{-1}$.

The mathematical curves are more or less close to the experimental mass gain curves. The fit is particularly good for the Ni-30Cr- $0.2 \mathrm{C}$ alloy at $1000^{\circ} \mathrm{C}$ and $1100^{\circ} \mathrm{C}$ (Fig. 6 b), but it is also very good for the other curves as shown by the perfect parallelism of the last parts of the mathematical curves and the experimental curves. In the case of a Ni-30\% Cr alloy the fit was also very good (Ref. 11).

\section{Metallographic results}

After the thermogravimetry tests, all samples were prepared for metallography and observed. Their surface and sub-surface states are shown in Fig. 7 for $1000^{\circ} \mathrm{C}$ and $1200^{\circ} \mathrm{C}$. All samples present an external oxide scale which was unfortunately partly lost during cooling after test. The high carbon alloy is also affected by internal oxidation and by appearance of voids at all temperatures, because of the disappearance of the coarse carbides that existed here for this alloy. External and internal oxides were identified by EDS and are all clearly $\mathrm{Cr}_{2} \mathrm{O}_{3}$. The two alloys also present a carbide-free zone between the external surface and the bulk, in which, for the Ni-30Cr-0.8C alloy, internal oxides and voids exist together. Between the carbide-free zone and the zone not affected by oxidation, a third zone exists in the Ni-30Cr- $0.2 \mathrm{C}$ alloy oxidized at $1000^{\circ} \mathrm{C}$. This zone is characterized by the precipitation of small acicular new carbides in matrix. As demonstrated and quantified in a previous work (Ref. 12), this is due to an inwards diffusion of the carbon released by the dissolving carbides which promotes the intergranular solid state formation of new carbides involving chromium present in solid solution in matrix. Other phenomena can be a growth or a change of stoichiometry of the interdendritic carbides which already existed here. 
The thicknesses of the external chromia layer and the depth of the carbide-free zone for all samples are shown in Table IV. The thickness of the external chromia layer logically increases with temperature for the two alloys. For the two lowest temperatures the chromia scale is sensibly thicker for the high carbon alloy than for the low carbon alloy while the two scales have almost the same thicknesses for $1200^{\circ} \mathrm{C}$. Except for $1000^{\circ} \mathrm{C}$, the carbide-free zone of the $\mathrm{Ni}-30 \mathrm{Cr}-0.2 \mathrm{C}$ alloy tends to be deeper than the one of the $\mathrm{Ni}-30 \mathrm{Cr}-0.8 \mathrm{C}$ alloy, as is to say they are inversely ordered compared to the bulk carbides density.

Two WDS Cr content profiles were performed per sample through the zone affected by oxidation. They are shown in Fig. 8 for $1000^{\circ} \mathrm{C}$ and $1200^{\circ} \mathrm{C}$. First, the chromium content of the matrix in the bulk is of course higher in the case of $\mathrm{Ni}-30 \mathrm{Cr}-0.2 \mathrm{C}$ for which almost all the chromium is contained in the matrix, than for Ni$30 \mathrm{Cr}-0.8 \mathrm{C}$ for which a significant part of the $30 \mathrm{wt} . \% \mathrm{Cr}$ is included in the intergranular carbides that are more present. Second, the chromium content gradient becomes lower for the two alloys when temperature rises while the $\mathrm{Cr}$-depletion depth increases. At each temperature the $\mathrm{Cr}$-gradient appears to be higher and the $\mathrm{Cr}$ depletion depth seems to be less extended for the Ni-30Cr-0.2C alloy than for the Ni-30Cr-0.8C.

\section{Assessment of the Chromium involved in Oxidation and Comparison between Thermogravimetry and Metallography Results}

The chromium mass per unit area that diffused towards the oxidation front can be estimated from the Cr-profiles by the sum of two terms. The first one is (equation 7):

$$
\mathrm{m}_{1}=\rho_{\text {alloy }} \cdot \Delta \mathrm{d} \cdot \sum_{\mathrm{i}=1}^{\mathrm{N}}\left[\mathrm{W}_{\text {Cr bulk }}-\mathrm{W}_{\mathrm{Cr}}(\mathrm{i})\right]
$$

where $\mathrm{m}_{1}$ is expressed in $\mathrm{g} \mathrm{cm}^{-2}, \rho_{\text {alloy }}$ is the density of the alloy (about $8.2 \mathrm{~g} \mathrm{~cm}^{-3}$ for the two alloys), $\Delta \mathrm{d}$ is the profile step (e.g. $5 \mu \mathrm{m}=5 \times 10^{-4} \mathrm{~cm}$ for samples oxidized at $1100^{\circ} \mathrm{C}$ ), $\mathrm{W}_{\mathrm{Cr} \text { bulk }}$ is the chromium weight content of the matrix in the bulk (e.g. $24.2 \%=0.242$ for $\mathrm{Ni}-30 \mathrm{Cr}-0.8 \mathrm{C}$ at $1100^{\circ} \mathrm{C}$, content measured by WDS microanalysis), $\mathrm{W}_{\mathrm{Cr}}$ (i) is the chromium weight content of the matrix at the depth $\mathrm{i} \times \Delta \mathrm{d}$ from the extreme surface, and $\mathrm{N}$ is the entire value of the ratio of the profile length divided by the step $\Delta \mathrm{d}$. The second one is (equation 8):

$$
\mathrm{m}_{2}=\rho_{\text {alloy }} \cdot \mathrm{d}_{\mathrm{cfz}} \cdot \mathrm{f}_{\mathrm{w}}\left(\mathrm{Cr}_{7} \mathrm{C}_{3}\right) \cdot \mathrm{W}_{\mathrm{Cr} \text { carb }}
$$

where $\mathrm{m}_{2}$ is expressed in $\mathrm{g} \mathrm{cm}^{-2}, \mathrm{~d}_{\mathrm{cfz}}$ is the depth of the carbide-free zone (e.g. $60 \mu \mathrm{m}=60 \times 10^{-4} \mathrm{~cm}_{\text {for }}$ Ni-30Cr- $0.8 \mathrm{C}$ oxidized at $\left.1100^{\circ} \mathrm{C}\right), \mathrm{f}_{\mathrm{w}}\left(\mathrm{Cr}_{7} \mathrm{C}_{3}\right)$ is the weight fraction of the $\mathrm{Cr}_{7} \mathrm{C}_{3}$ carbide in the alloy bulk at the considered temperature (e.g. $8.51 \%=0.0851$ for $\mathrm{Ni}-30 \mathrm{Cr}-0.8 \mathrm{C}$ at $1100^{\circ} \mathrm{C}$, calculated using the ThermoCalc TCW software and its SSOL database), and $\mathrm{W}_{\mathrm{Cr} \text { carb }}$ the weight content of chromium in $\mathrm{the}_{7} \mathrm{Cr}_{3}$ carbides (e.g. $91 \%=0.91)$.

The chromium quantity per unit area present on the external surface with the form $\mathrm{Cr}_{2} \mathrm{O}_{3}\left(\mathrm{~m}_{3}\right.$ expressed in $\mathrm{g}$ $\mathrm{cm}^{-2}$ ), can be estimated from the average chromia thicknesses $\mathrm{d}_{\text {oxide }}$ (expressed in $\mathrm{cm}$ here and in $\mu \mathrm{m}$ in Table $\mathrm{IV})$, its density $\rho_{\text {oxide }}\left(5.2 \mathrm{~g} \mathrm{~cm}^{-3}\right)$ and the molar weights of $\mathrm{Cr}\left(\mathrm{M}_{\mathrm{Cr}}=52 \mathrm{~g} \mathrm{~mol}^{-1}\right)$ and of $\mathrm{Cr}_{2} \mathrm{O}_{3}\left(\mathrm{M}_{\mathrm{Cr} 2 \mathrm{O} 3}=152 \mathrm{~g}\right.$ $\mathrm{mol}^{-1}$ ) by (equation 9$)$ :

$$
\mathrm{m}_{3}=\rho_{\text {oxide }} \cdot\left(\frac{2 \cdot \mathrm{M}_{\mathrm{Cr}}}{\mathrm{M}_{\mathrm{Cr}_{2} \mathrm{O}_{3}}}\right) \cdot \mathrm{d}_{\text {oxide }}
$$

The chromium lost by volatilization of chromia can be determined by equation (10):

$$
\mathrm{m}_{4}=\frac{2 \cdot \mathrm{M}_{\mathrm{Cr}}}{\mathrm{M}_{\mathrm{Cr} 2 \mathrm{O} 3}} \cdot \mathrm{K}_{\mathrm{v}} \cdot \Delta \mathrm{t}=0.684 \cdot \mathrm{K}_{\mathrm{v}} \cdot \Delta \mathrm{t}
$$

where $\mathrm{m}_{4}$ is expressed in $\mathrm{g} \mathrm{cm}^{-2}, \mathrm{~K}_{\mathrm{v}}$ is the volatilization constant (e.g. $85.1 \times 10^{-10} \mathrm{~g} \mathrm{~cm}^{-2} \mathrm{~s}^{-1}$ for Ni$30 \mathrm{Cr}-0.8 \mathrm{C}$ at $\left.1100^{\circ} \mathrm{C}\right)$ and $\Delta \mathrm{t}$ is the test duration $(180,000 \mathrm{~s})$.

If the $\mathrm{K}_{\mathrm{v}}$ determination was correct the following equation (11) must be verified:

$$
\mathrm{m}_{1}+\mathrm{m}_{2}=\mathrm{m}_{3}+\mathrm{m}_{4}
$$

The values of the four chromium quantities for the two alloys and the three temperatures are presented in Table V. For the Ni-30Cr-0.2C alloy there is, for the three temperatures, a good correspondence between on 
the one hand the mass of chromium that left the alloy, and on the other hand the sum of chromium present in the $\mathrm{Cr}_{2} \mathrm{O}_{3}$ layer and of chromium that disappeared as gaseous $\mathrm{CrO}_{3}$. On the contrary, for the Ni-30Cr- $0.8 \mathrm{C}$ alloy, the mass of chromium lost by the alloy is always higher than the total mass of oxidized chromium, although the two quantities have the same order of magnitude. This can probably be explained by the presence of internal chromium oxides in the case of this alloy, which was not taken into account in the chromium balance sheet.

\section{Diffusion of Chromium during Oxidation}

It was remarked in the previous section that the chromium gradient was higher for $\mathrm{Ni}-30 \mathrm{Cr}-0.2 \mathrm{C}$ than for $\mathrm{Ni}-30 \mathrm{Cr}-0.8 \mathrm{C}$. In addition most of the $\mathrm{Cr}$ profiles appear to often contain an extended part of linear variation of the chromium content versus the distance from the extreme surface (Fig. 8). Knowing now the kinetics of oxidation of chromium on the external surface it is possible to better know how the density of intergranular carbides can influence the diffusion of chromium.

Here the first Fick's law was simply considered. It can be written as follows (equation 12):

$$
\frac{\mathrm{dn}_{\mathrm{Cr}}}{\mathrm{dt}}=-\mathrm{D}_{\mathrm{Cr}} \cdot \operatorname{grad} \mathrm{C}_{\mathrm{Cr}}
$$

where $\mathrm{dn}_{\mathrm{Cr}}$ is the number of $\mathrm{Cr}$ moles per unit area (expressed in $\mathrm{mol} \mathrm{cm}{ }^{-2}$ ) that reached the oxidation front during $\mathrm{dt}$ (expressed in $\mathrm{s}$ ) at the end of experiment to be oxidised first into $\mathrm{Cr}_{2} \mathrm{O}_{3}, \mathrm{D}_{\mathrm{Cr}}$ is the average diffusion coefficient of chromium through the alloy (expressed in $\mathrm{cm}^{2} \mathrm{~s}^{-1}$ ), and $\operatorname{grad} \mathrm{C}_{\mathrm{Cr}}$ (expressed in mol $\mathrm{cm}^{-4}$ ) is the value of the gradient of concentration of chromium $\mathrm{C}_{\mathrm{Cr}}$ (expressed in $\mathrm{mol} \mathrm{cm} \mathrm{cm}^{-3}$ ).

The second term of this equation is equal to $\mathrm{D}_{\mathrm{Cr}} \cdot\left(\frac{\rho_{\text {alloy }}}{\mathrm{M}_{\mathrm{Cr}}}\right) \cdot\left(\frac{\Delta \mathrm{W}_{\mathrm{Cr}}}{\Delta \mathrm{x}}\right)$ i. e. to $\mathrm{D}_{\mathrm{Cr}}$ multiplied by the product of, on the one hand the alloy density divided by the molar weight of $\mathrm{Cr}$, and on the other hand the value of the $\mathrm{Cr}$ weight content gradient.

The first term is equal to the final value (i.e. at $t=180,000 \mathrm{~s})$ of $\frac{2}{3} \cdot \frac{\mathrm{dn}_{\mathrm{O}}}{\mathrm{dt}}\left(\right.$ noted $\left.\frac{2}{3} \cdot \frac{\mathrm{dn}_{\mathrm{O}}}{\mathrm{dt}}\right|_{\text {end }}$ ), where $\mathrm{n}_{\mathrm{O}}$ is the number by unit area of oxygen moles involved first by the growth of chromia, then to $\left.\frac{2}{3 \mathrm{M}_{\mathrm{O}}} \cdot \frac{\mathrm{dm}_{\mathrm{O}}}{\mathrm{dt}}\right|_{\text {end }}$. When volatilization of chromia can be neglected, e.g. when $\mathrm{T}$ is not higher than $1000^{\circ} \mathrm{C},\left.\frac{\mathrm{dm}_{\mathrm{O}}}{\mathrm{dt}}\right|_{\text {end }}$ is equal to the final value (i.e. at $t=180,000$ s) of the derived function of the measured surface mass gain $\left.\frac{\mathrm{dm}}{\mathrm{dt}}\right|_{\text {end }}$. When the volatilization of chromia must be taken into account, the measured mass gain $\mathrm{dm}$ is equal at each time to $\mathrm{dm}_{\mathrm{O}}-\mathrm{K}_{\mathrm{v}} \cdot \mathrm{dt}$ and $\left.\frac{\mathrm{dm}_{\mathrm{O}}}{\mathrm{dt}}\right|_{\text {end }}$ is given by $\left.\frac{\mathrm{dm}}{\mathrm{dt}}\right|_{\text {end }}+\mathrm{K}_{\mathrm{v}}$. Then, for all cases, the coefficient of the Cr diffusion is (equation 13):

$$
\mathrm{D}_{\mathrm{Cr}}=\frac{2 \mathrm{M}_{\mathrm{Cr}}}{3 \mathrm{M}_{\mathrm{O}}} \cdot \frac{\left.\frac{\mathrm{dm}}{\mathrm{dt}}\right|_{\text {end }}+\mathrm{K}_{\mathrm{V}}}{\rho_{\text {alloy }} \cdot \frac{\Delta \mathrm{W}_{\mathrm{Cr}}}{\Delta \mathrm{x}}}
$$

where $\mathrm{D}_{\mathrm{Cr}}$ is in $\mathrm{cm}^{2} \mathrm{~s}^{-1},\left.\frac{\mathrm{dm}}{\mathrm{dt}}\right|_{\text {end }}$ in $\mathrm{g} \mathrm{cm}^{-2} \mathrm{~s}^{-1}, \mathrm{~K}_{\mathrm{v}}$ in $\mathrm{g} \mathrm{cm}^{-2} \mathrm{~s}^{-1}, \rho_{\text {alloy }}=8.2 \mathrm{~g} \mathrm{~cm}^{-3}$ and $\frac{\Delta \mathrm{W}_{\mathrm{Cr}}}{\Delta \mathrm{x}}$ in cm${ }^{-1}$.

The knowledge of both the Cr gradient and the final mass gain kinetics leads to the assessment of the chromium diffusion coefficient. The values obtained for the two alloys and the three temperatures are presented in Table VI, together with the corresponding values calculated from the results for the Ni-30wt.\%Cr alloy (Ref. 11). Several observations can be done. First the chromium gradient, which decreases with 
temperature, also depends on the alloy. Indeed the gradient across the carbide-free zone appears to be lower when the density of carbides is higher, for all temperatures. In addition a second gradient is visible, at all temperatures, deeper in the $\mathrm{Ni}-30 \mathrm{Cr}-0.8 \mathrm{C}$ alloy where carbides still exist, while such a gradient is visible only for $1000^{\circ} \mathrm{C}$ for the $\mathrm{Ni}-30 \mathrm{Cr}-0.2 \mathrm{C}$ alloy. The $\mathrm{Cr}$ gradients measured for the $\mathrm{Ni}-30 \% \mathrm{Cr}$ alloy (Ref. 11) are close to the $\mathrm{Cr}$ gradients for the Ni-30Cr-0.2C alloy which differs from the latter alloy only by a small quantity of carbides. The $\mathrm{Cr}$ diffusion coefficient, calculated as described above, logically increases with temperature for all alloys and it seems to be, for all temperatures, higher for $\mathrm{Ni}-30 \mathrm{Cr}-0.8 \mathrm{C}$ than for $\mathrm{Ni}-30 \mathrm{Cr}-0.2 \mathrm{C}$, and higher for $\mathrm{Ni}-30 \mathrm{Cr}-0.2 \mathrm{C}$ than for $\mathrm{Ni}-30 \% \mathrm{Cr}$.

\section{DISCUSSION}

First, the values obtained for $\mathrm{K}_{\mathrm{p}}$ appear to be consistent with the results observed earlier on similar alloys based on Ni-30wt.\% Cr and oxidized in air, e.g. about $60 \times 10^{-12} \mathrm{~g}^{2} \mathrm{~cm}^{-4} \mathrm{~s}^{-1}$ at $1200^{\circ} \mathrm{C}$ (Ref. 13), or logically lower than other parabolic constants obtained for $P_{O 2}=1$ atm, e.g. about $20 \times 10^{-12} \mathrm{~g}^{2} \mathrm{~cm}^{-4} \mathrm{~s}^{-1}$ at $1000^{\circ} \mathrm{C}$ (Ref. 14), and $90 \times 10^{-12}\left(1100^{\circ} \mathrm{C}\right)$ and $220 \times 10^{-12} \mathrm{~g}^{2} \mathrm{~cm}^{-4} \mathrm{~s}^{-1}\left(1200^{\circ} \mathrm{C}\right)$ (Ref. 15).

Second, the values obtained for $\mathrm{K}_{\mathrm{v}}$ are of the same order of magnitude as volatilization constants previously measured by other techniques directly on $\mathrm{Cr}_{2} \mathrm{O}_{3}, 37 \times 10^{-10} \mathrm{~g} \mathrm{~cm}^{-2} \mathrm{~s}^{-1}\left(1100^{\circ} \mathrm{C}\right)$ and $124 \times 10^{-10} \mathrm{~g} \mathrm{~cm}^{-2} \mathrm{~s}^{-1}$ $\left(1200^{\circ} \mathrm{C}\right.$ ) (Ref. 16), and $83 \times 10^{-10} \mathrm{~g} \mathrm{~cm}^{-2} \mathrm{~s}^{-1}\left(1100^{\circ} \mathrm{C}\right)$ and $280 \times 10^{-10} \mathrm{~g} \mathrm{~cm}^{-2} \mathrm{~s}^{-1}$ (1200 $\left.{ }^{\circ} \mathrm{C}\right)$ (Ref. 17).

The density of carbides seems to have a real effect on the global oxidation rate of these simple cast alloys. It was already seen on more complex alloys (Ref. 6), but only for the parabolic constant. With the measurement of the transient oxidation rate and the double determination of the parabolic and volatilization constants

allowed by the $\left\{\mathrm{m} \cdot \frac{\mathrm{dm}}{\mathrm{dt}}=\mathrm{K}_{\mathrm{p}}-\mathrm{K}_{\mathrm{v}} \cdot \mathrm{m}\right\}$ - type treatment of the thermogravimetry results, it appeared here that

a higher carbide density leads to higher linear $\mathrm{K}_{1}$ constants, to higher parabolic constants $\mathrm{K}_{\mathrm{p}}$ again, and seemingly to higher volatilization constants $K_{v}$ too. This influence is obvious for the $K_{1}$ and $K_{p}$ constants between the two carbides-containing alloys, and can be explained, for the Ni-30Cr-0.8C alloy, by an easier nucleation of chromia on its external surface which can be supposed because of the higher density of emerging chromium carbides for this alloy. This could first act by a more dense nucleation of oxide, and thereafter to a more rapid mass gain by growth of chromia perpendicular to the extreme surface until the scale becomes continuous. Thereafter, the higher grain boundaries density obtained in the structure of this external oxide (due to the initial more dense nucleation) could promote an easier diffusion of the species involved in the oxidation phenomena, then a higher mass gain rate characterized by the higher $\mathrm{K}_{\mathrm{p}}$ values which were seen here. This is also true when $\mathrm{K}_{\mathrm{p}}$ and $\mathrm{K}_{\mathrm{v}}$ constants previously measured on the Ni-30wt.\%Cr alloy with the same method of $\left(\mathrm{K}_{\mathrm{p}}, \mathrm{K}_{\mathrm{v}}\right)$ determination, are also considered. Indeed they are lower than for the Ni-30Cr-0.2C alloy and for the $\mathrm{Ni}-30 \mathrm{Cr}-0.8 \mathrm{C}$ alloy. The presence of carbides and a higher density of these ones can help the diffusion of chromium towards the oxidation front. When the mass gain rates and chromium profiles are analysed together, the coefficients of chromium diffusion can be assessed. Their values clearly show that the chromium carbides have effectively a real influence on the diffusion easiness of chromium. When present with a higher density, they lead to higher diffusion coefficients. Since they contain a part of chromium in the carbides the grain boundaries act as good diffusion paths for chromium and this contribution is added to the volume diffusion of chromium. When the intergranular carbides have disappeared, grain boundaries in the carbide-free zone are probably more disordered if the intergranular carbides were initially more present. Then chromium certainly diffuses easier through the grain boundaries of the carbide-free zone for the Ni-30Cr-0.8C alloy than for the other alloys. Concerning the kinetic of chromia volatilization, some differences were also seen between the $\mathrm{K}_{\mathrm{v}}$ values obtained for the carbides-richest alloy and the two others. One can think that the finer structure of the Ni-30Cr-0.8C external oxide, due to its more dense initial nucleation, allowed a faster new oxidation of chromia.

During oxidation, the chromium carbides disappear from the oxidation front on a depth which increases with time, and also with temperature. The depth of the carbide-free zone also depends of the density of the initial carbides since it is deeper for the Ni-30Cr- $0.2 \mathrm{C}$ alloy than for the Ni-30Cr-0.8C one (except for $1000^{\circ} \mathrm{C}$ where a part of the carbon obviously remained in the first alloy between the carbide-free zone and the bulk), a phenomena which was already encountered in previous works (Ref. 12). Even if the contribution of 
the chromium carbides to the $\mathrm{Cr}$ quantity supplied on the oxidation front is lower for the Ni-30Cr-0.2C alloy than for the Ni-30Cr-0.8C alloy (Table V), the carbides of the first alloy necessarily dissolve deeper than for the second alloy, because of its less dense initial carbides network.

To finish, one can remark than the method used here to know both the $\mathrm{K}_{\mathrm{p}}$ and $\mathrm{K}_{\mathrm{v}}$ constants, which allowed this double determination for a particularly simple chromia-forming alloy (Ni-30wt.\% Cr) in a previous work (Ref. 11), was successfully used here for alloys that contain chromium carbides, although the more complex microstructures lead to thermogravimetry curves that are less parabolic then not so easy to exploit according to this method. But the chromia volatilization constants, then also the parabolic constants, were correctly assessed. Indeed, on the one hand the mathematical curves are close to the experimental thermogravimetry ones, and on the other hand the chromium balance sheet which was dressed up between the metallography measurements and the quantified chromium loss by chromia volatilization is well respected (or the differences can be explained by the internal oxidation).

\section{CONCLUSION}

The thermogravimetry runs and their treatment in order to extract all the different oxidation constants allowed to clearly show that the presence and the density of the interdendritic carbides network of cast nickel alloys are of a great importance on their high temperature oxidation behavior. The oxidation kinetics (transient, parabolic and re-oxidation of chromia) increase when the carbides density of the alloy increases. Moreover, the determination of the $\mathrm{K}_{\mathrm{v}}$ constants allowed to know more precisely the whole chromium quantity that arrives on the oxidation front, then to obtain the $\mathrm{Cr}$ diffusion coefficients. This led to clearly see that the interdendritic chromium carbides facilitate the $\mathrm{Cr}$ diffusion towards the oxidation front. In addition this appears to be a possible method to measure the diffusion coefficients of chromium at high temperature, which can also be used for the determination of high temperature diffusion coefficients of other elements that can be easily oxidised: $\mathrm{Al}, \mathrm{Si}, \mathrm{Ti}, \mathrm{Ta}, \ldots$

It appears also that the treatment based on the $m \cdot \frac{d m}{d t}=K_{p}-K_{v} \cdot m$ differential equation, which already gave good results for a binary alloy, is also efficient for alloys containing chromium carbides and it allows the determination of the volatilization constant and a more precise parabolic constant. This method remains to be tried on other more complex chromia-forming alloys, e.g. containing other types of carbides.

\section{ACKNOWLEDGEMENTS}

The author thanks Lionel Aranda (thermogravimetry runs) and the Microanalysis Common Service of the Faculty of Science of Nancy, especially Sophie Adeline (WDS measurements and concentrations profiles). 


\section{REFERENCES}

1. P. Kofstad, High Temperature Corrosion, Elsevier applied science, 1988.

2. $\quad$ C. T. Sims and W. C. Hagel, The Superalloys, John Wiley \& Sons, 1972.

3. E. F. Bradley, Superalloys: A Technical Guide, ASM International, 1988.

4. J. Di Martino, C. Rapin, P. Berthod, R. Podor, and P. Steinmetz, Corrosion Science, 46, 1849-1864 (2004)

5. J. Di Martino, C. Rapin, P. Berthod, R. Podor, and P. Steinmetz, Corrosion Science, 46, 1865-1881 (2004)

6. J. Di Martino, S. Michon, L. Aranda, P. Berthod, R. Podor, and C. Rapin, Ann. Chim. Sci. Mat. , 28 Suppl. 1, S231-S238 (2003)

7. J. Di Martino, Oxydation à haute temperature et corrosion par le verre C3 de superalliages base cobalt, PhD Thesis, University of Nancy 1 France, 2002.

8. C. Wagner, Z. Phys. Chem., 21, 25-41 (1933)

9. B. Gaillard-Allemand, Etude de la corrosion de matériaux métalliques et céramiques par le verre de confinement des déchets nucléaires fondus, PhD Thesis, University of Nancy 1 France, 2001.

10. S. Diliberto, C. Rapin, P. Steinmetz, M. Vilasi, and P. Berthod, Journal of Materials Science, 38, 2063-2072 (2003)

11. P. Berthod, Oxidation of Metals, 64, 235-252 (2005)

12. P. Berthod, C. Vébert, L. Aranda, R. Podor, and C. Rapin, Oxidation of Metals, 63 57-72 (2005)

13. C.S. Giggins, and F.S. Pettit, Metallurgical Transactions, 2(4), 1071-1078 (1971)

14. I.G. Wright, Oxidation of iron, nickel and cobalt base alloys, MCIC Report (1972).

15. P. Moulin, A.M. Huntz, and P. Lacombe, Acta Metallurgica, 28, 745-756 (1980)

16. W.C. Hagel, Transactions of the ASM, 56, 583-599 (1963)

17. C .A. Stearns, F.J. Kohl, and G.C. Fryburg, J. Electrochem. Soc. , 121/7, 945-951 (1974) 
Table I. Chemical compositions of the two obtained alloys

(average and standard deviation values from three EDS measurements on each alloy)

\begin{tabular}{ccccccc}
\hline Chemical & \multicolumn{3}{c}{$\mathrm{Ni}-30 \mathrm{Cr}-0.2 \mathrm{C}$} & \multicolumn{3}{c}{$\mathrm{Ni}-30 \mathrm{Cr}-0.8 \mathrm{C}$} \\
\cline { 2 - 6 } composition (wt.\%) & $\mathrm{Ni}$ & $\mathrm{Cr}$ & $\mathrm{C}$ & $\mathrm{Ni}$ & $\mathrm{Cr}$ & $\mathrm{C}$ \\
average contents & 70.46 & 29.54 & $\cong 0.2$ & 70.76 & 29.24 & $\cong 0.8$ \\
standard deviation & 0.21 & 0.21 & $/$ & 0.71 & 0.71 & $/$ \\
\hline
\end{tabular}

Table II. Values of the transient linear oxidation constant $\mathrm{K}_{1}$ for the two alloys and with assessment of the corresponding activation energies

\begin{tabular}{ccccc}
\hline $\mathbf{K}_{\mathbf{l}}\left(\times 10^{-8} \mathrm{~g} \mathrm{~cm}^{-2} \mathrm{~s}^{-1}\right)$ & $1000^{\circ} \mathrm{C}$ & $1100^{\circ} \mathrm{C}$ & $1200^{\circ} \mathrm{C}$ & $\begin{array}{c}\text { Activation energy } \\
\left(\mathrm{kJ} \mathrm{mol}^{-1}\right)\end{array}$ \\
\hline Ni-30Cr-0.8C & 18.3 & 30.5 & 44.2 & 69 \\
Ni-30Cr-0.2C & 7.1 & 23.3 & 60.0 & 166 \\
Ni-30\%Cr $*$ & 5.1 & 17.7 & 29.7 & 167 \\
\hline
\end{tabular}

* (alloy previously studied in Ref. 11)

Table III. Values of the parabolic oxidation constant $\mathrm{K}_{\mathrm{p}}$ and of the chromia volatilization constant $\mathrm{K}_{\mathrm{v}}$ for the two alloys with assessment of the corresponding activation energies

\begin{tabular}{rccccc}
\hline $\begin{array}{r}\mathbf{K}_{\mathrm{p}}\left(\times 10^{-12} \mathrm{~g}^{2} \mathrm{~cm}^{-4} \mathrm{~s}^{-1}\right) \\
\mathrm{K}_{\mathrm{v}}\left(\times 10^{-10} \mathrm{~g} \mathrm{~cm}^{-2} \mathrm{~s}^{-1}\right)\end{array}$ & & $1000^{\circ} \mathrm{C}$ & $1100^{\circ} \mathrm{C}$ & $1200^{\circ} \mathrm{C}$ & $\begin{array}{c}\text { Activation } \\
\text { energies } \\
\left(\mathrm{kJ} \mathrm{mol}^{-1}\right)\end{array}$ \\
\hline Ni-30Cr-0.8C & $\mathbf{K}_{\mathbf{p}}$ & $\mathbf{8 . 7}$ & $\mathbf{5 4 . 5}$ & $\mathbf{1 7 7}$ & $\mathbf{2 0 4}$ \\
& $\mathrm{K}_{\mathrm{v}}$ & 15.1 & 85.1 & 142 & 177 \\
Ni-30Cr-0.2C & $\mathbf{K}_{\mathbf{p}}$ & $\mathbf{5 . 9}$ & $\mathbf{2 9 . 4}$ & $\mathbf{7 7}$ & $\mathbf{2 0 1}$ \\
& $\mathrm{K}_{\mathrm{v}}$ & 19.2 & 60.4 & 125 & 147 \\
Ni-30\%Cr * & $\mathbf{K}_{\mathbf{p}}$ & $\mathbf{2 . 8}$ & $\mathbf{1 8 . 1}$ & $\mathbf{6 4}$ & $\mathbf{2 3 9}$ \\
& $\mathrm{K}_{\mathrm{v}}$ & $0.72^{* *}$ & 64.7 & 134 & $122^{* *}$ \\
\hline
\end{tabular}

* (alloy previously studied in Ref. 11);

** (value for $1000^{\circ} \mathrm{C}$ not precise and not taken into account for the determination of the activation energy)

Table IV. Average values and standard deviation for the thickness of the external chromia layer $\mathrm{e}_{\mathrm{Cr} 2 \mathrm{O} 3}$ and for the depth of the carbide-free zone $\mathrm{d}_{\mathrm{cfz}}$ (about 20 measures per sample in each case)

\begin{tabular}{ccccccc}
\hline External $\mathrm{Cr}_{2} \mathrm{O}_{3}$ thickness $(\mu \mathrm{m})$ & \multicolumn{2}{c}{$1000^{\circ} \mathrm{C}$} & \multicolumn{2}{c}{$1100^{\circ} \mathrm{C}$} & \multicolumn{2}{c}{$1200^{\circ} \mathrm{C}$} \\
\cline { 2 - 7 } Carbide-free zone depth $(\mu \mathrm{m})$ & $\mathrm{e}_{\mathrm{Cr} 2 \mathrm{O} 3}$ & $d_{c f z}$ & $\mathrm{e}_{\mathrm{Cr} 2 \mathrm{O} 3}$ & $d_{c f z}$ & $\mathrm{e}_{\mathrm{Cr} 203}$ & $d_{c f z}$ \\
\hline $\mathrm{Ni}-30 \mathrm{Cr}-0.8 \mathrm{C}$ & 8.7 & 27.0 & 14.3 & 60.1 & 26.5 & 105 \\
& \pm 1.4 & \pm 2.2 & \pm 1.6 & \pm 6.0 & \pm 1.1 & \pm 6 \\
$\mathrm{Ni}-30 \mathrm{Cr}-0.2 \mathrm{C}$ & 3.7 & 18.4 & 11.4 & 90.7 & 25.1 & 197 \\
& \pm 0.7 & \pm 2.8 & \pm 2.1 & \pm 10.7 & \pm 1.5 & \pm 12 \\
\hline
\end{tabular}


Table V. Chromium balance sheets for the two alloys and the three temperatures

\begin{tabular}{|c|c|c|c|c|c|c|}
\hline \multirow{2}{*}{$\begin{array}{c}\mathbf{N i - 3 0 C r - 0 . 8 C} \\
\quad\left(\mathrm{mg} \mathrm{cm}^{-2}\right)\end{array}$} & \multicolumn{2}{|c|}{ Cr lost by the alloy } & \multirow[b]{2}{*}{ Total Alloy } & \multicolumn{2}{|c|}{ Oxidized $\mathrm{Cr}$} & \multirow[b]{2}{*}{ Total Oxides } \\
\hline & matrix & carbides & & $\mathrm{Cr}_{2} \mathrm{O}_{3}$ & volat. $\mathrm{CrO}_{3}$ & \\
\hline $1200^{\circ} \mathrm{C}$ & $\begin{array}{c}\mathrm{m}_{1} \\
9.82\end{array}$ & $\begin{array}{c}\mathrm{m}_{2} \\
6.29\end{array}$ & 16.11 & $\begin{array}{c}\mathrm{m}_{3} \\
9.42\end{array}$ & $\begin{array}{c}\mathrm{m}_{4} \\
1.75\end{array}$ & 11.17 \\
\hline $1100^{\circ} \mathrm{C}$ & 6.48 & 3.72 & 10.20 & 5.09 & 1.05 & 6.14 \\
\hline $1000^{\circ} \mathrm{C}$ & 2.07 & 1.71 & 3.79 & 3.08 & 0.19 & 3.27 \\
\hline \multirow{2}{*}{$\begin{array}{l}\mathbf{N i - 3 0 C r - 0 . 2 C} \\
\quad\left(\mathrm{mg} \mathrm{cm}^{-2}\right)\end{array}$} & \multicolumn{2}{|c|}{ Cr lost by the alloy } & & \multicolumn{2}{|c|}{ Oxidized $\mathrm{Cr}$} & \\
\hline & $\begin{array}{c}\text { matrix } \\
\mathrm{m}_{1}\end{array}$ & $\begin{array}{c}\text { carbides } \\
\mathrm{m}_{2}\end{array}$ & Total Alloy & $\begin{array}{c}\mathrm{Cr}_{2} \mathrm{O}_{3} \\
\mathrm{~m}_{3}\end{array}$ & $\begin{array}{c}\text { volat. } \mathrm{CrO}_{3} \\
\mathrm{~m}_{4}\end{array}$ & Total Oxides \\
\hline $1200^{\circ} \mathrm{C}$ & 7.48 & 2.60 & 10.07 & 8.94 & 1.54 & 10.48 \\
\hline $1100^{\circ} \mathrm{C}$ & 5.10 & 1.30 & 6.39 & 4.07 & 0.74 & 4.81 \\
\hline $1000^{\circ} \mathrm{C}$ & 2.01 & 0.28 & 2.29 & 1.31 & 0.24 & 1.54 \\
\hline
\end{tabular}

Table VI. Weight content gradients and diffusion coefficients of chromium through the zone affected by oxidation

\begin{tabular}{|c|c|c|c|c|}
\hline \multirow[t]{2}{*}{ Cr-profiles } & \multicolumn{2}{|c|}{$\begin{array}{l}\text { Weight content chromium gradients } \\
\qquad \frac{\Delta \mathrm{W}_{\mathrm{Cr}}}{\Delta \mathrm{x}}\left(\mathrm{wt} . \% \times \mu \mathrm{m}^{-1}\right)\end{array}$} & \multicolumn{2}{|c|}{$\begin{array}{l}\text { Cr diffusion coefficient } \\
\qquad \mathrm{D}_{\mathrm{Cr}}\left(\times 10^{-10} \mathrm{~cm}^{2} \mathrm{~s}^{-1}\right)\end{array}$} \\
\hline & $\begin{array}{l}\text { carbide-free } \\
\text { zone }\end{array}$ & $\begin{array}{c}\text { deeper } \\
\text { (if not negligible) }\end{array}$ & $\begin{array}{l}\text { carbide-free } \\
\text { zone }\end{array}$ & $\begin{array}{c}\text { deeper } \\
\text { (if not negligible) }\end{array}$ \\
\hline \multicolumn{5}{|l|}{ Ni-30Cr-0.8C } \\
\hline $\begin{array}{c}1200^{\circ} \mathrm{C} \\
(50 \text { hours })\end{array}$ & 0.014 & 0.011 & 44.5 & 56.6 \\
\hline $\begin{array}{c}1100^{\circ} \mathrm{C} \\
(50 \text { hours })\end{array}$ & 0.040 & 0.033 & 10.1 & 12.3 \\
\hline $\begin{array}{c}1000^{\circ} \mathrm{C} \\
\text { (50 hours) }\end{array}$ & 0.203 & 0.061 & 0.69 & 2.30 \\
\hline \multicolumn{5}{|l|}{$\mathrm{Ni}-30 \mathrm{Cr}-0.2 \mathrm{C}$} \\
\hline $\begin{array}{c}1200^{\circ} \mathrm{C} \\
(50 \text { hours })\end{array}$ & 0.029 & I & 17.5 & I \\
\hline $\begin{array}{c}1100^{\circ} \mathrm{C} \\
(50 \text { hours })\end{array}$ & 0.104 & l & 2.89 & / \\
\hline $\begin{array}{c}1000^{\circ} \mathrm{C} \\
\text { (50 hours) }\end{array}$ & 0.274 & 0.173 & 0.46 & 0.73 \\
\hline \multicolumn{5}{|l|}{$\mathrm{Ni}-30 \% \mathrm{Cr} *$} \\
\hline $\begin{array}{c}1200^{\circ} \mathrm{C} \\
\text { (50 hours) }\end{array}$ & 0.031 & I & 15.8 & / \\
\hline $\begin{array}{c}1100^{\circ} \mathrm{C} \\
(50 \text { hours })\end{array}$ & 0.094 & / & 2.81 & l \\
\hline $\begin{array}{c}1000^{\circ} \mathrm{C} \\
(50 \text { hours })\end{array}$ & 0.349 & / & 0.17 & / \\
\hline
\end{tabular}

* (alloy previously studied in Ref. 11) 


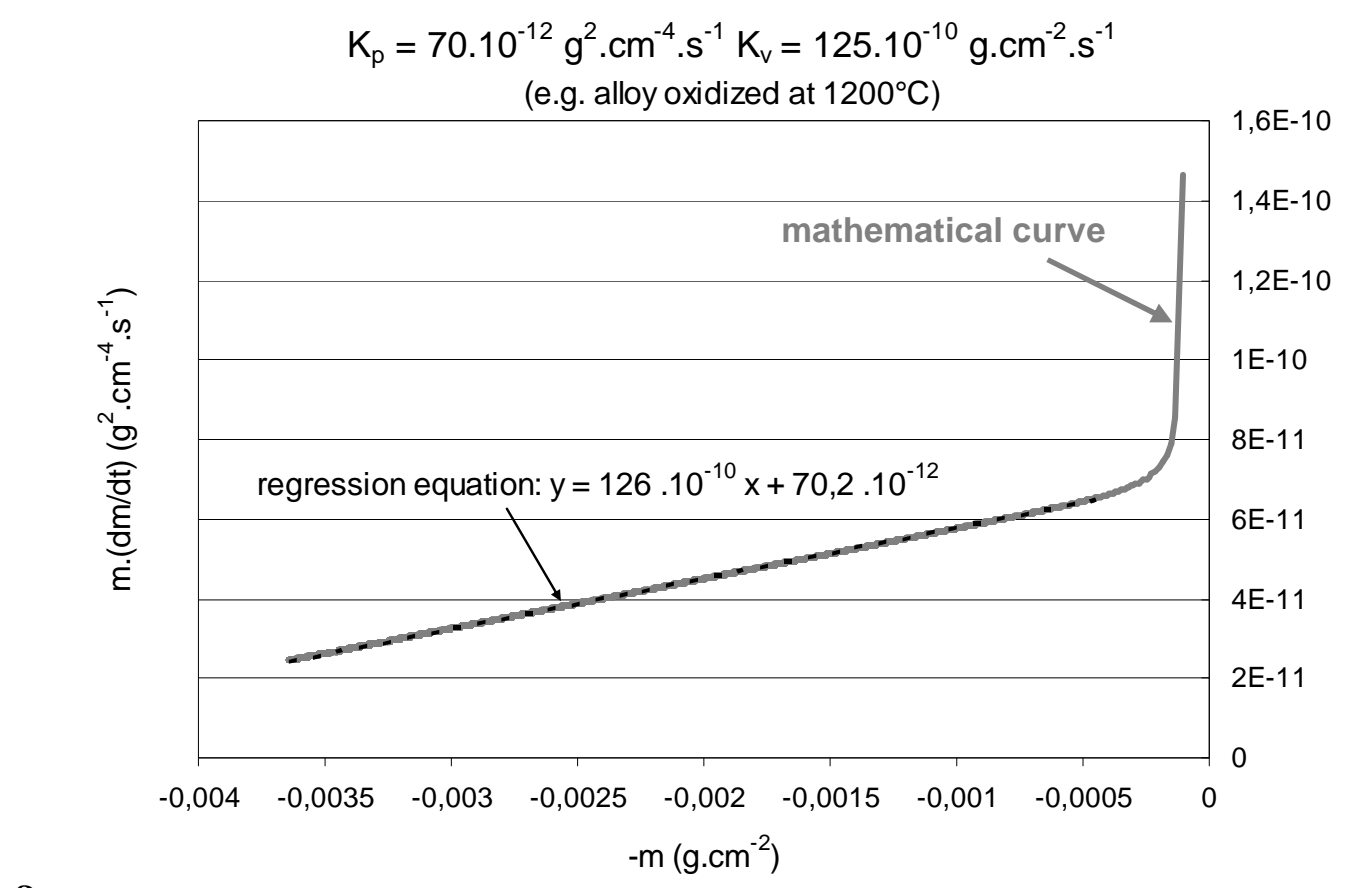

a

$$
\mathrm{K}_{\mathrm{p}}=5 \cdot 10^{-12} \mathrm{~g}^{2} \cdot \mathrm{cm}^{-4} \cdot \mathrm{s}^{-1} \mathrm{~K}_{\mathrm{v}}=0 \mathrm{~g} \cdot \mathrm{cm}^{-2} \cdot \mathrm{s}^{-1}
$$

(e.g. alloy oxidized at $1000^{\circ} \mathrm{C}$ )

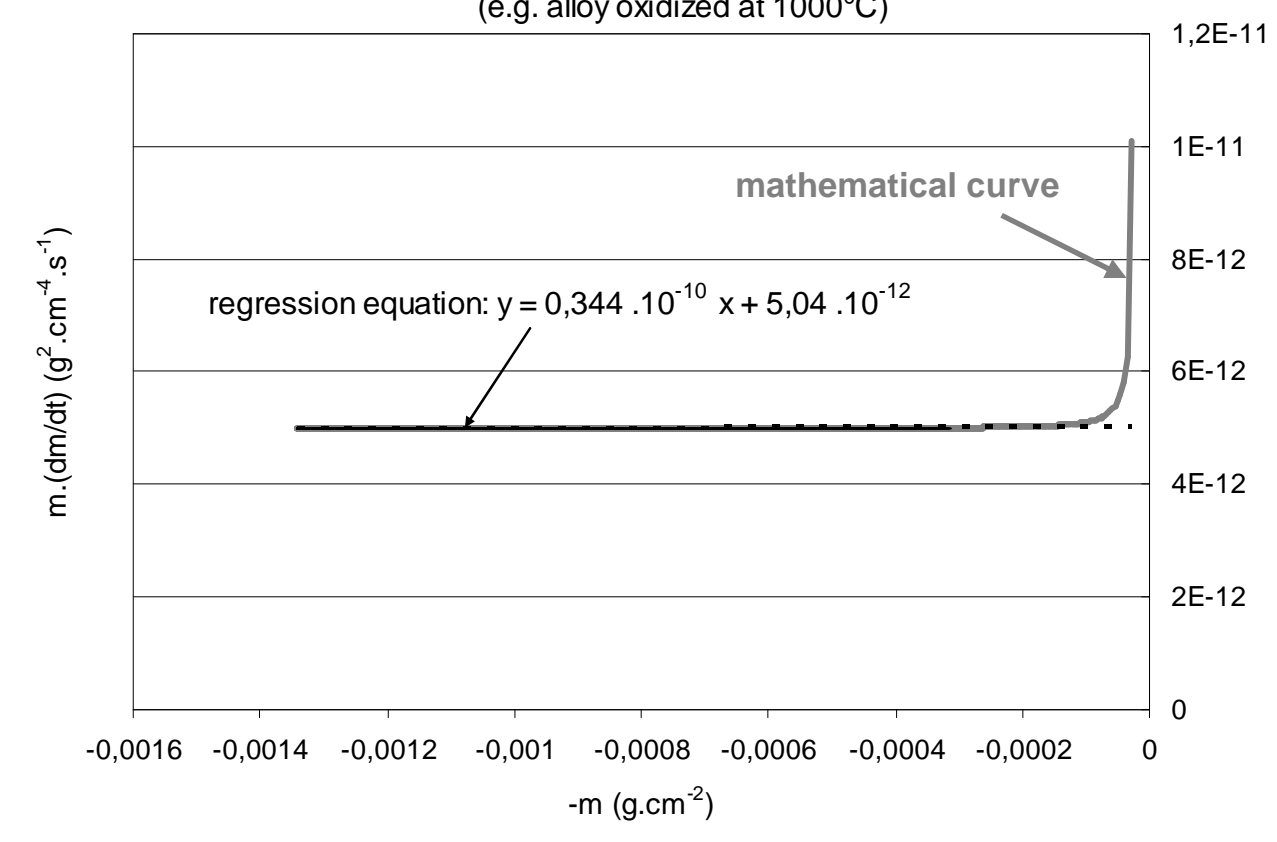

a (very high temperature): the volatilization of chromia occurs $->$ tilted straight line

b (lower temperature): the volatilization of chromia is not significant $->$ horizontal straight line

Fig. 1. Two examples of synthetic curves built with data calculated from $\left\{\mathrm{dm}_{\mathrm{n}+1}=\left(\mathrm{K}_{\mathrm{p}} / \mathrm{m}_{\mathrm{n}}\right) \cdot \mathrm{dt}-\mathrm{K}_{\mathrm{v}} \cdot \mathrm{dt}\right\}$ for chosen $\mathrm{K}_{\mathrm{p}}$ and $\mathrm{K}_{\mathrm{v}}$, and here plotted in the $\mathrm{m} .(\mathrm{dm} / \mathrm{dt})=\mathrm{f}(-\mathrm{m})$ scheme; comparison between constants obtained according to equation (2) and the values initially used 


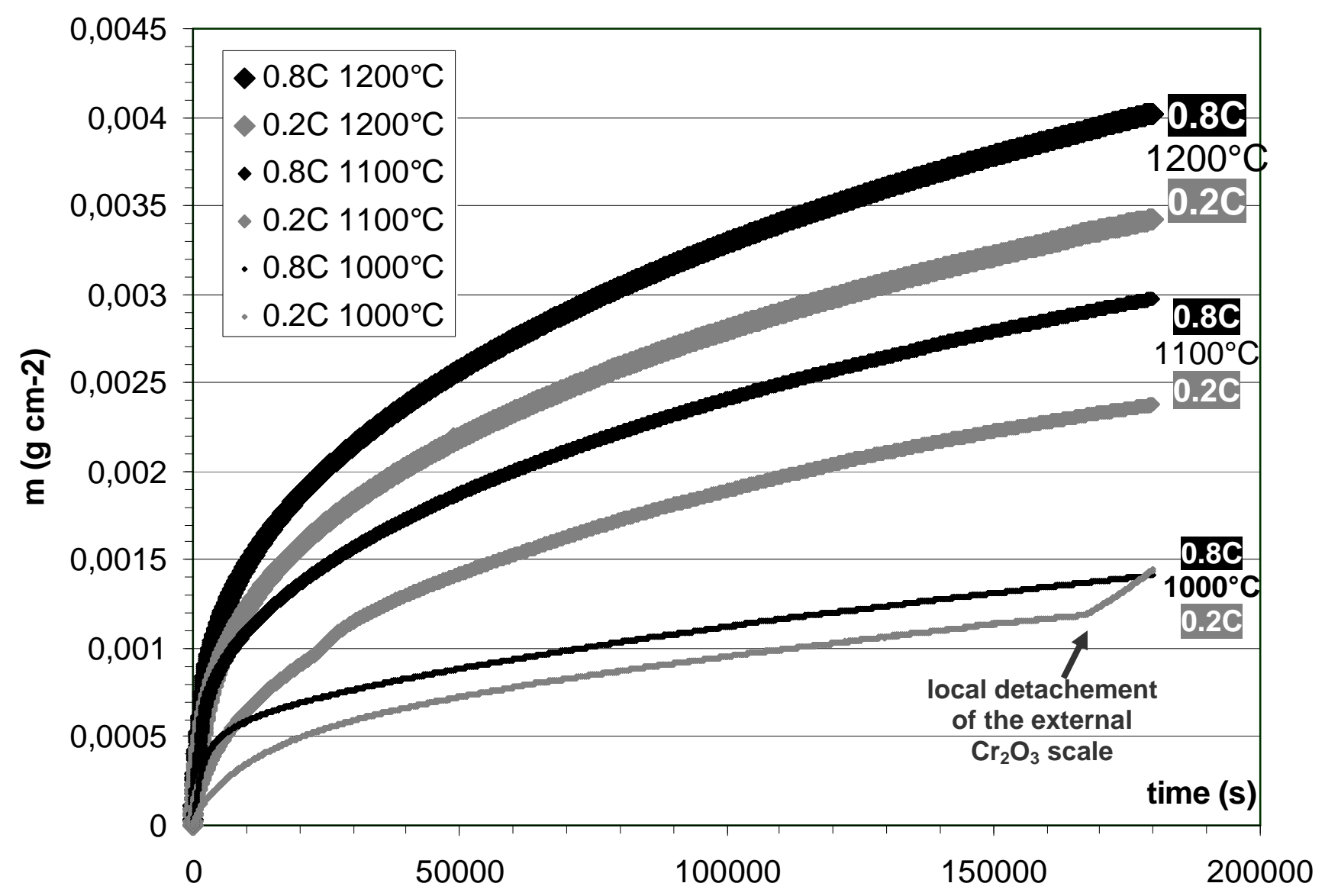

Fig. 2. The obtained thermogravimetry curves for the two Ni-30Cr-xC alloys $(\mathrm{x}=0.2$ or 0.8$)$ at 1200,1100 and $1000^{\circ} \mathrm{C}$ 


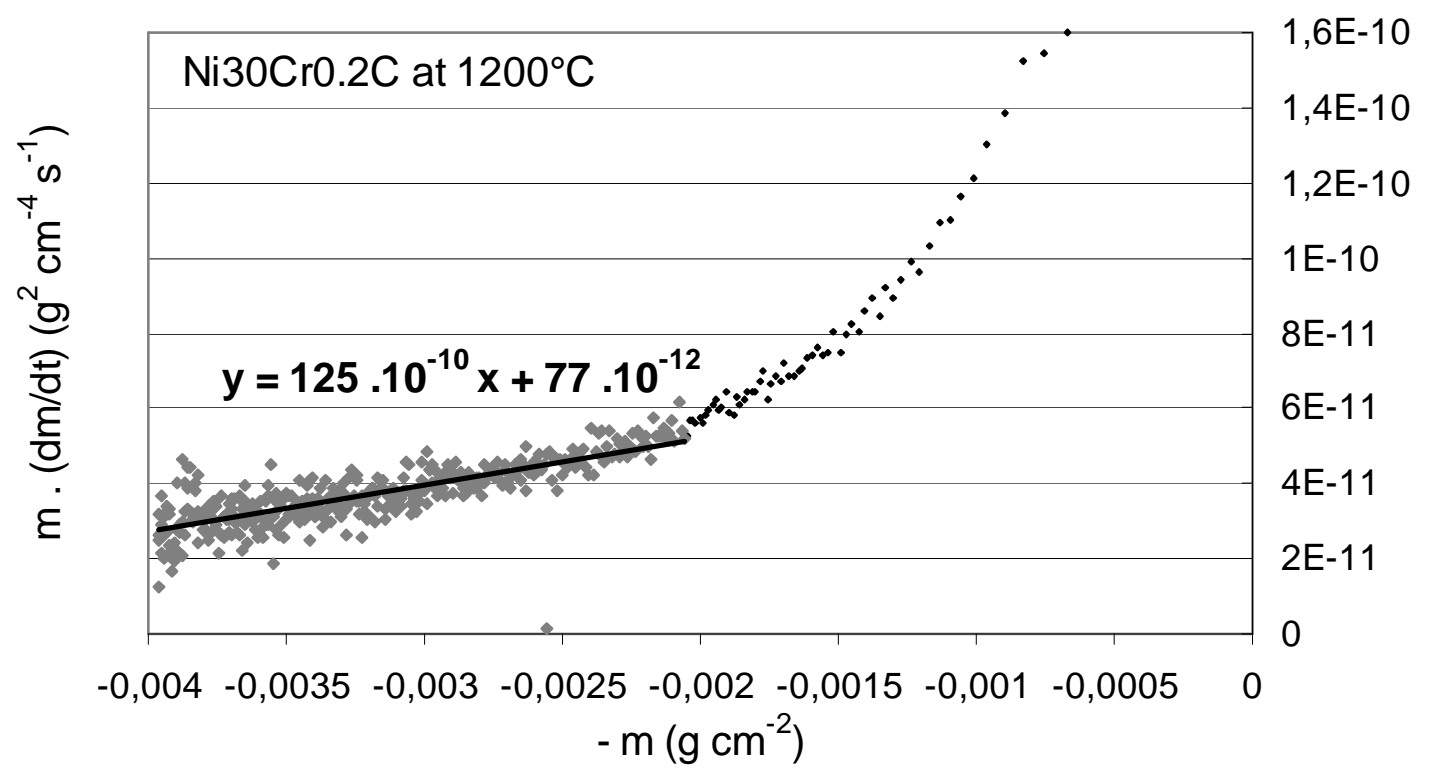

a

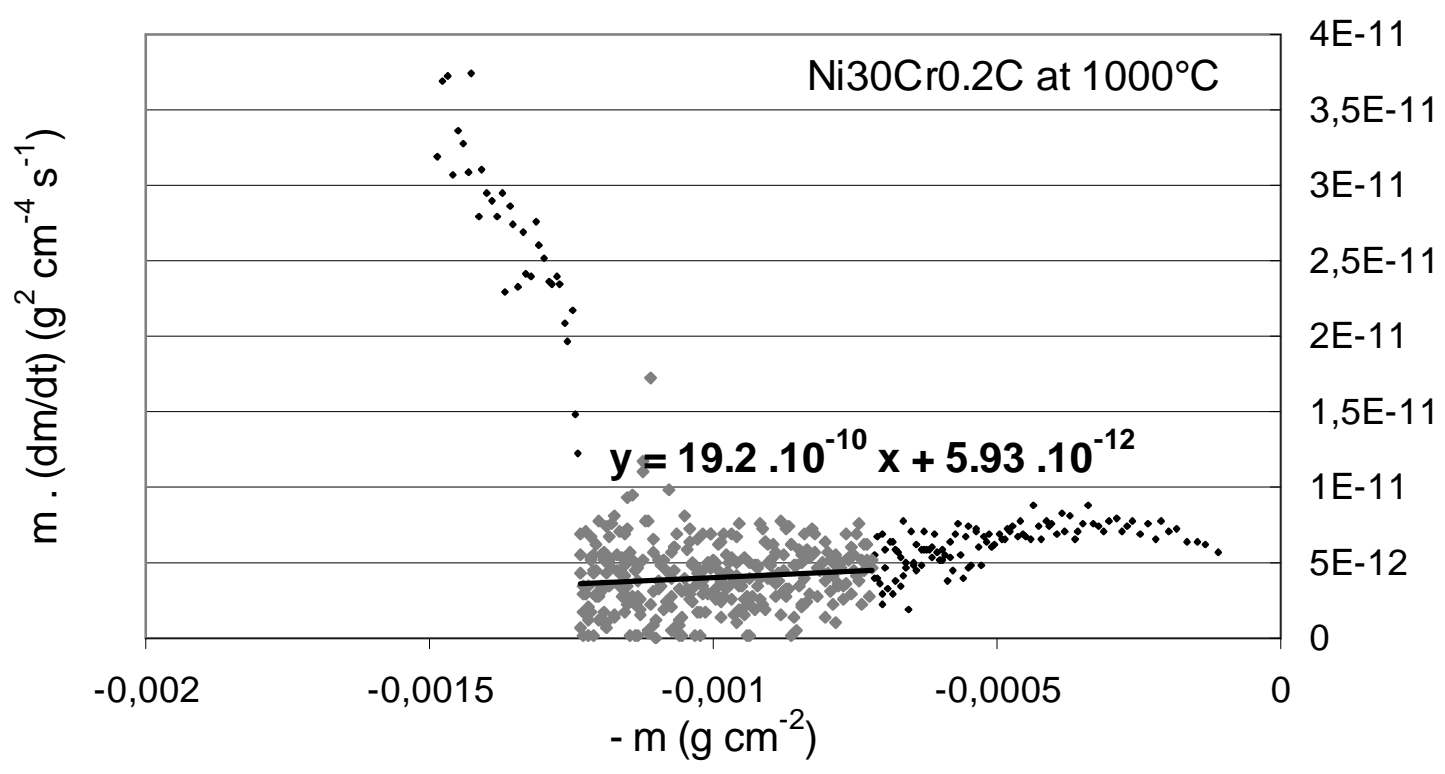

Fig. 3. $\mathrm{m}$. (dm/dt) plotted versus (-m) for the Ni-30Cr- $0.2 \mathrm{C}$ alloy $\left(\mathbf{a}: 1200^{\circ} \mathrm{C}, \mathbf{b}: 1000^{\circ} \mathrm{C}\right)$ 


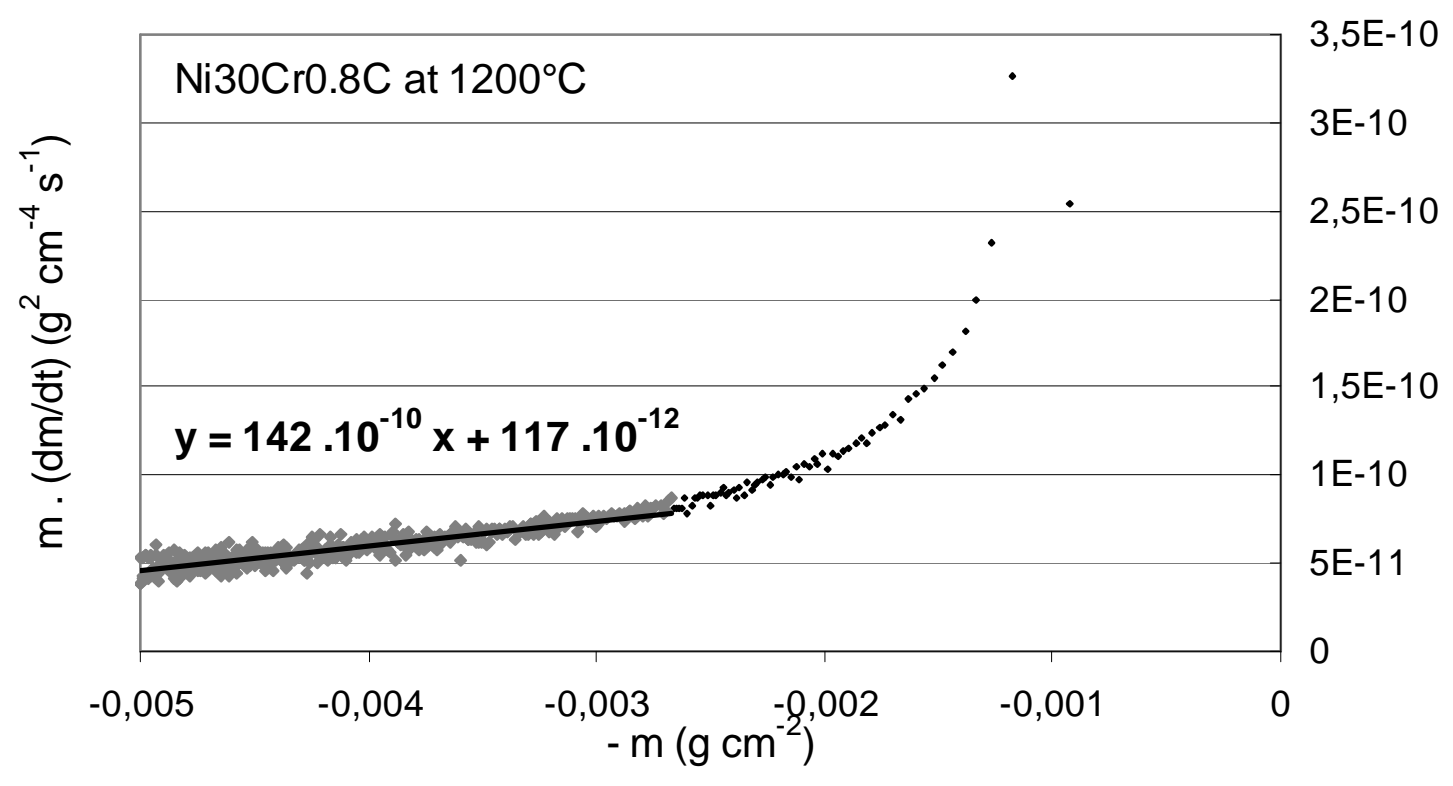

a

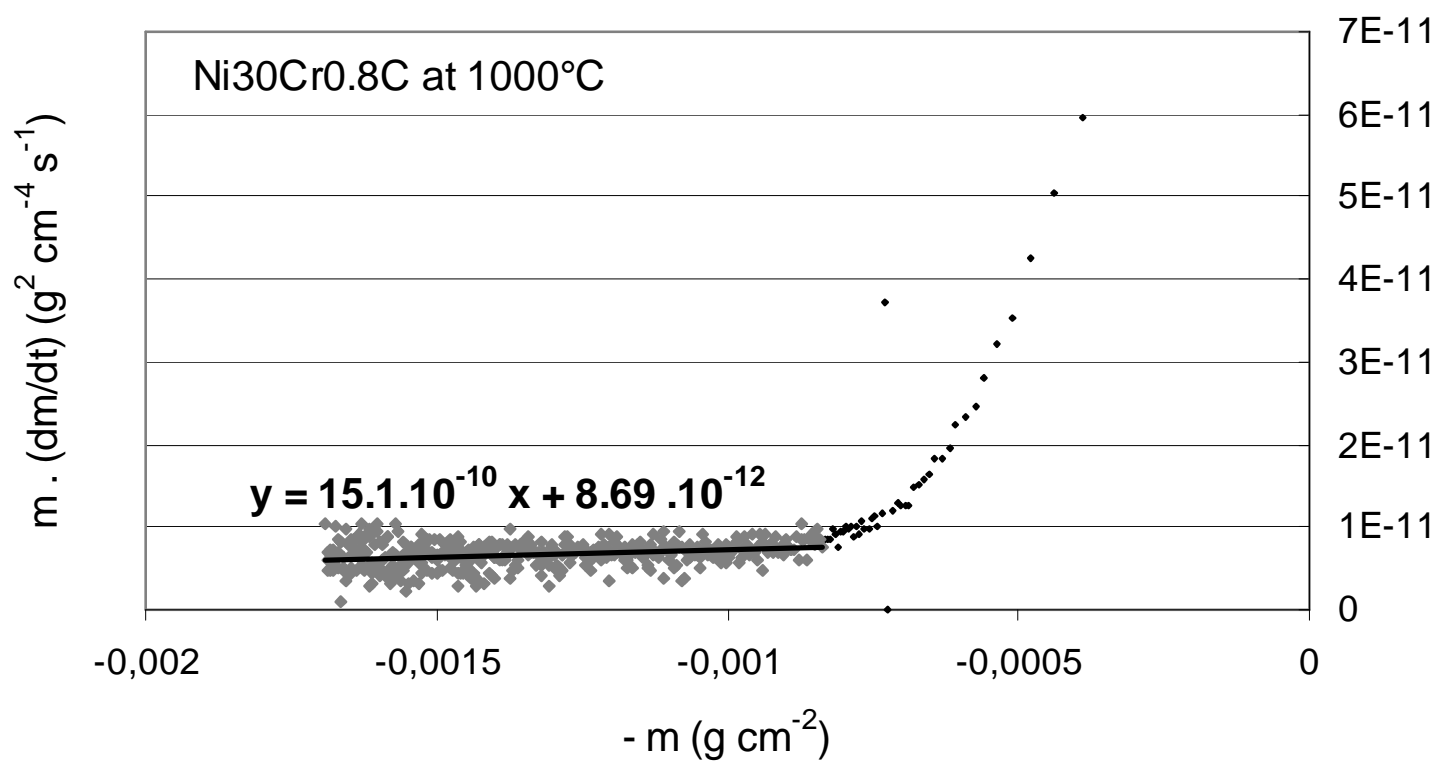

Fig. 4. $\mathrm{m}$. (dm/dt) plotted versus (-m) for the Ni-30Cr-0.8C alloy $\left(\mathbf{a}: 1200^{\circ} \mathrm{C}, \mathbf{b}: 1000^{\circ} \mathrm{C}\right)$ 

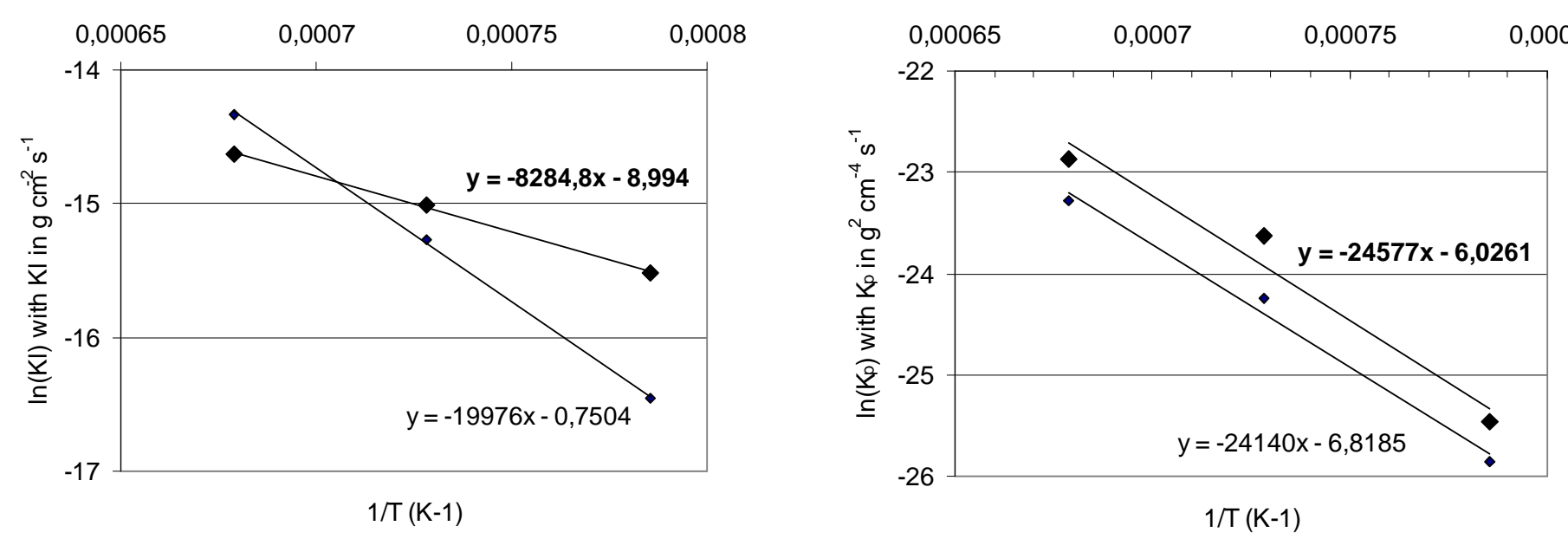

a

b

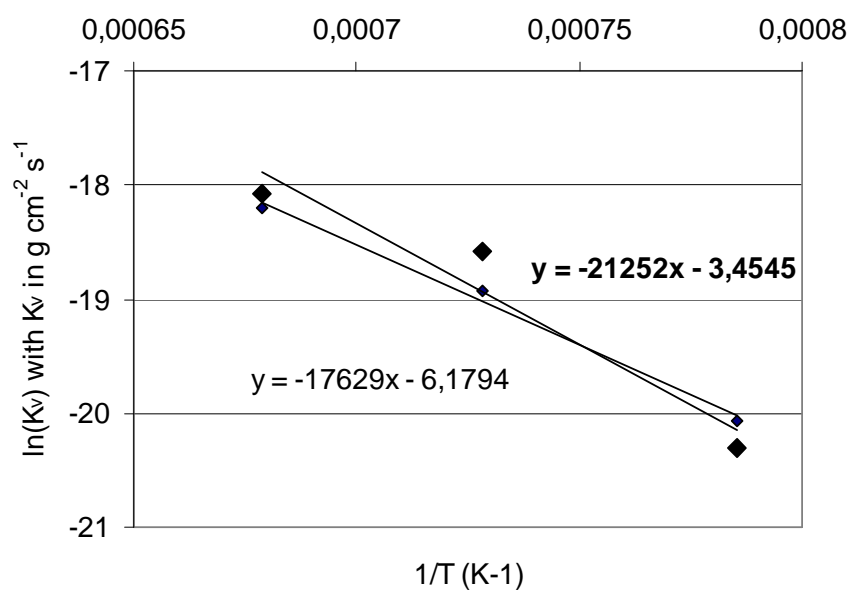

c

Fig. 5. Arrhenius-type plot of the $\mathrm{K}_{1}(\mathbf{a}), \mathrm{K}_{\mathrm{p}}(\mathbf{b})$ and $\mathrm{K}_{\mathrm{v}}(\mathbf{c})$ constants versus temperature corresponding to the

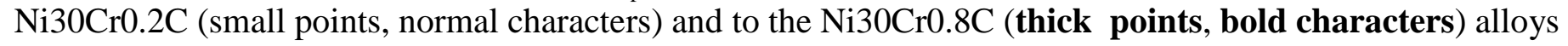



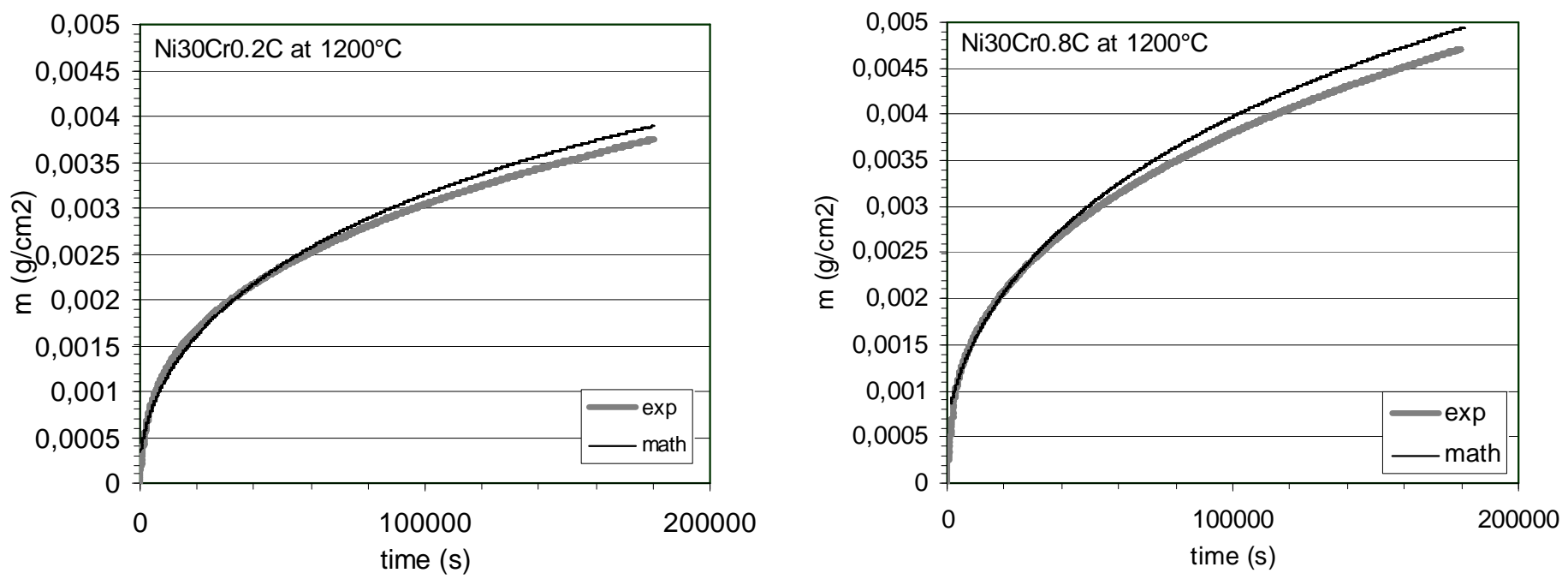

a

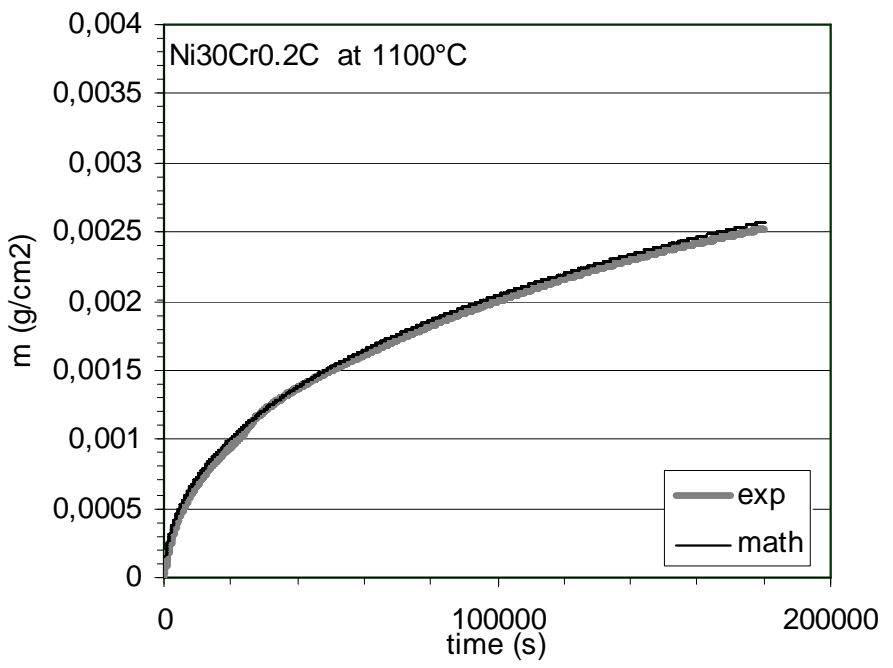

c

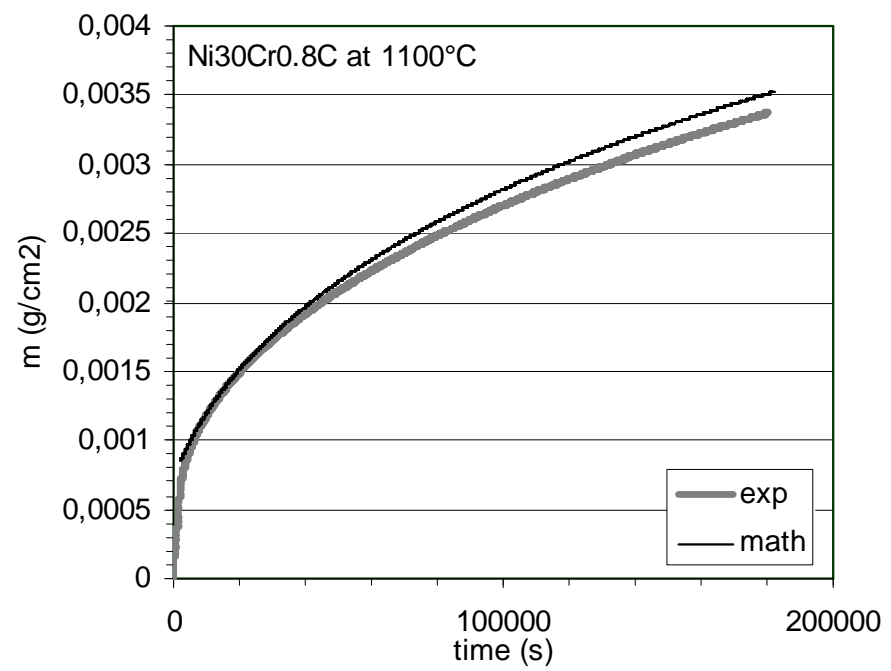

d

Fig. 6. Comparison between the mathematical curves and the experimental thermogravimetry curves for the $\mathrm{Ni} 30 \mathrm{Cr} 0.2 \mathrm{C}$ alloy at $1200^{\circ} \mathrm{C}(\mathbf{a})$ and $1100^{\circ} \mathrm{C}(\mathbf{b})$ and for the $\mathrm{Ni} 30 \mathrm{Cr} 0.8 \mathrm{C}$ alloy at $1200^{\circ} \mathrm{C} \mathrm{(c)} \mathrm{and} 1100^{\circ} \mathrm{C}(\mathbf{d})$ 


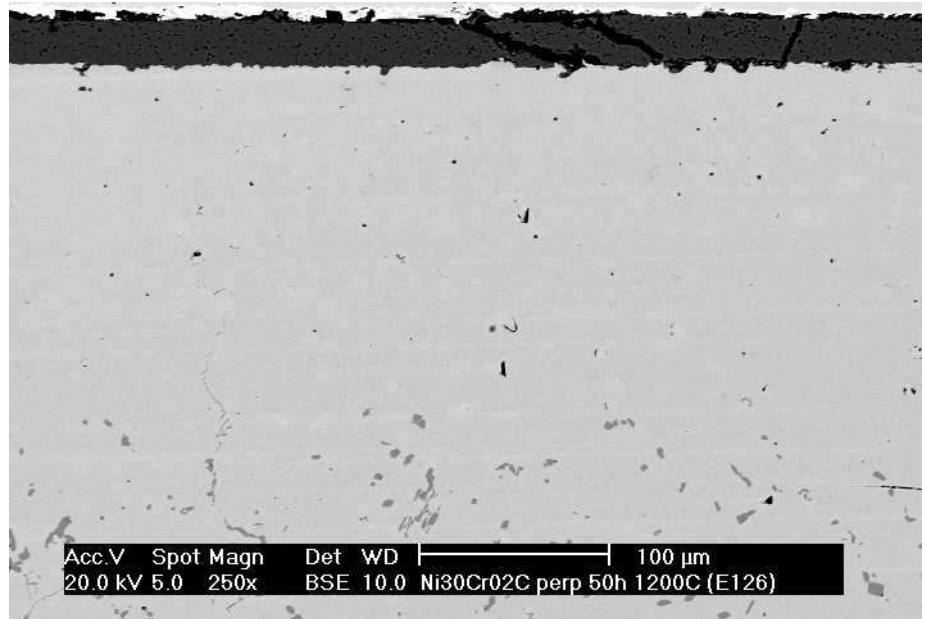

a $\mathrm{Ni}-30 \mathrm{Cr}-0.2 \mathrm{C}$ after 50 hours at $1200^{\circ} \mathrm{C}$

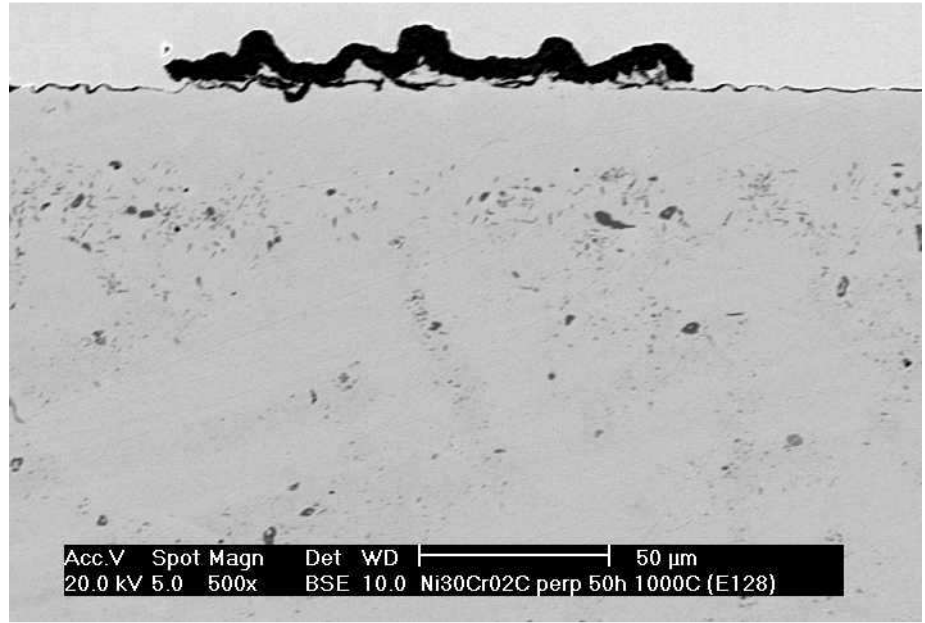

b $\mathrm{Ni}-30 \mathrm{Cr}-0.2 \mathrm{C}$ after 50 hours at $1000^{\circ} \mathrm{C}$

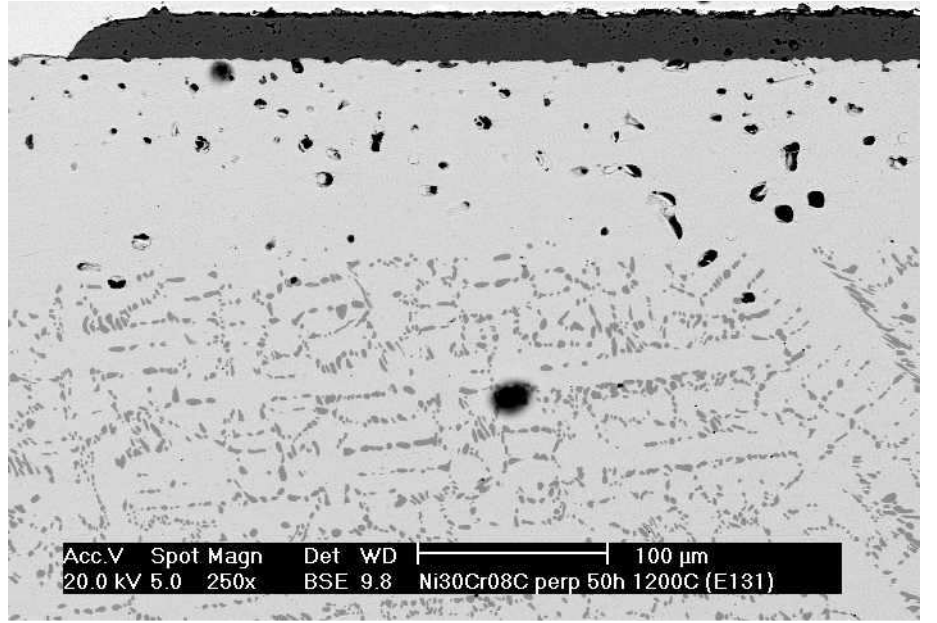

c $\mathrm{Ni}-30 \mathrm{Cr}-0.8 \mathrm{C}$ after 50 hours at $1200^{\circ} \mathrm{C}$

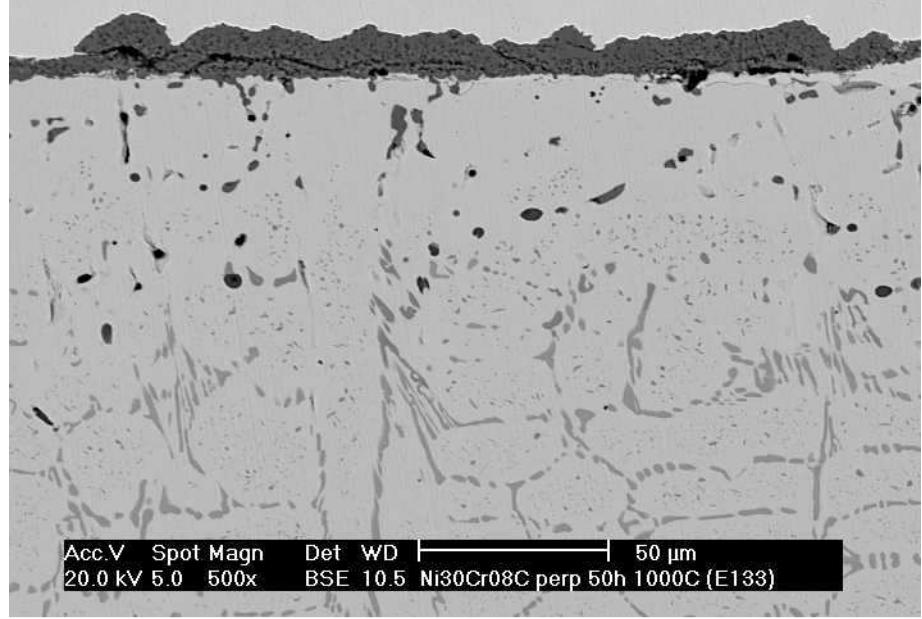

d $\mathrm{Ni}-30 \mathrm{Cr}-0.8 \mathrm{C}$ after 50 hours at $1000^{\circ} \mathrm{C}$

Fig. 7. External chromia layer and sub-surface state of the alloys oxidized for 50 hours:

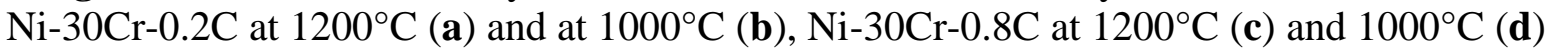



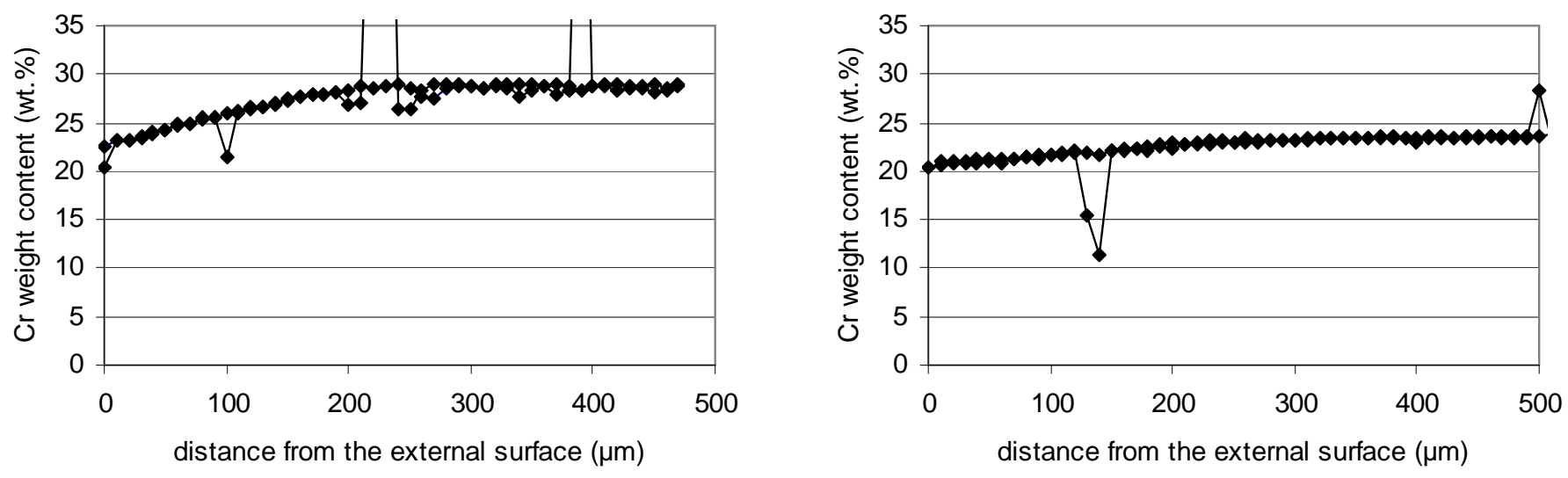

a

c
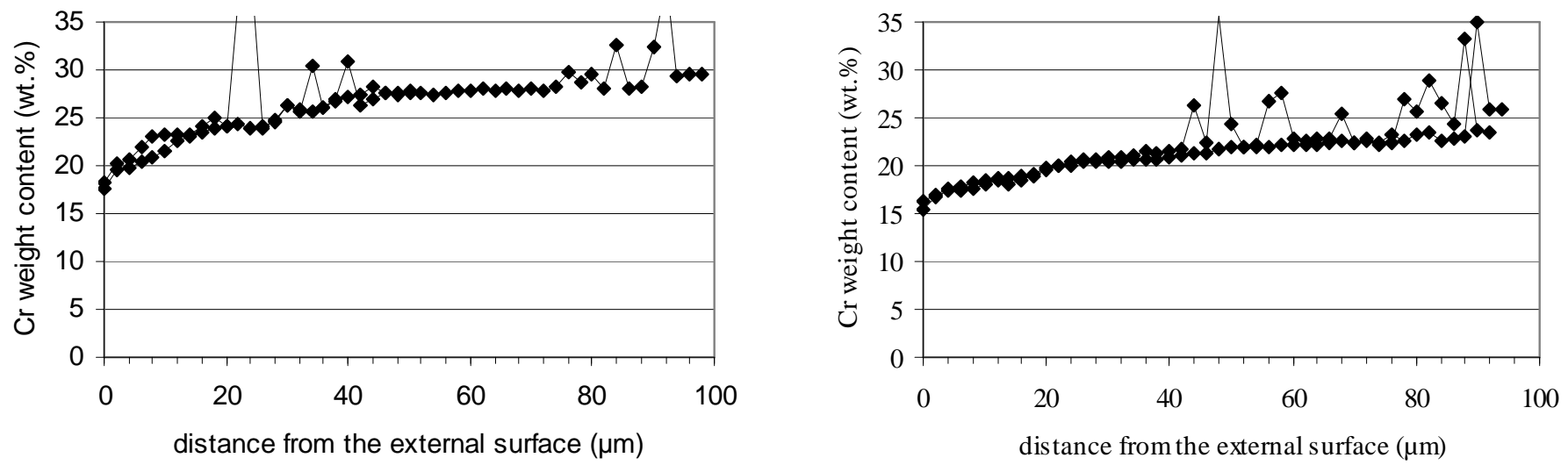

b

d

Fig. 8. Chromium profiles across the sub-surface affected by the 50 hours oxidation ( 2 profiles per sample):

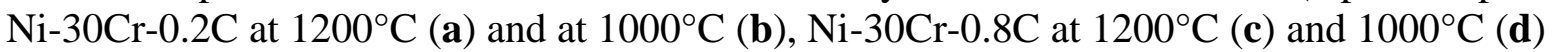

